\title{
RELATIONSHIP BETWEEN MINERALOGY AND THE PHYSICO-CHEMICAL PROPERTIES OF TILL IN CENTRAL FINLAND
}

\author{
MARJA LIISA RÄISÄNEN, MARKKU TENHOLA and JARI MÄKINEN
}

\begin{abstract}
RÄISÄNEN, MARJA LIISA, TENHOLA, MARKKU and MÄKINEN, JARI, 1992: Relationship between mineralogy and the physico-chemical properties of till in central Finland. Bull. Geol. Soc. Finland 64, Part 1, 35-58.

The chemical and physical characteristics of the fine fraction of till were examined in the area of the Raahe-Ladoga metallogenic belt in central Finland. Till, weathered bedrock and rock samples were collected from the area, where element concentrations of till abruptly ranged from high in an anomalous zone (NE) to low in a non-anomalous zone (SW). The grain size distribution, specific surface area and unit weight, and the leachability of elements measured with several chemical methods were determined from the fine fraction $(<0.06 \mathrm{~mm})$ of till. The mineralogical composition of the fine fraction of till and weathered bedrock was established with the X-ray diffraction method (XRD), and the chemical composition of rock samples with the X-ray fluorescence method (XRF).

The main factor affecting the increased element concentrations in the anomalous zone is the variation in mica and clay mineral types. The abundance of trioctahedral micas (biotite) and vermiculitic clays carrying most of the trace metals dissolved in aqua regia, has affected to the geochemical pattern of till in the study area. The concentrations of trace metals in the iron precipitates extracted with acid oxalate were too low to be used as evidence of the hydromorphic origin of the anomalous zone. The abundance of main silicates (quartz, feldspars) does not vary much in the fine fraction of till throughout the study area.

The absence of the swelling smectite component from the surface layers of till indicates that the source was not the underlying weathered bedrock. The till with a vermiculitic mixed-layer mineral in the anomalous zone contains more material from old sediments weathered during interstadial or interglacial time than does the till with a low clay content in the non-anomalous zone. The abrupt change in the mineralogical and physical properties of till in the study area is suggested to be attributed to the difference in the transport and accumulation dynamics of overburden during deglaciation.
\end{abstract}

Key words: geochemistry, till, clay mineralogy, mica group, weathering, specific surface, unit weight, bedrock, central Finland

Marja Liisa Räisänen, Markku Tenhola, Jari Mäkinen: Geological Survey of Finland, P.O.Box 1237, SF-70701 Kuopio, Finland.

\section{Introduction}

The element composition and dispersal patterns of transported overburden can be attributed to several factors. Regional differences in till geochemistry are mainly explained by the variation in the chemical composition and structure of the underlying bedrock (Shilts 1980, Salminen \& 
Hartikainen 1985, Koljonen et al. 1989). Moreover, the rate of glacial erosion and comminution, and intermixing with older sediments have heavily obscured the regional dispersal patterns in some till areas (Shilts 1973, Linden 1975, Kauranne et al. 1977, Rencz \& Shilts 1980, Peuraniemi 1990).

Regional geochemical mapping in Finland is based on low density sampling using $<0.06 \mathrm{~mm}$ till fractions. Trace metals in the fine fraction of till vary owing to changes in the lithological character of the bedrock (Kauranne 1959, Nikkarinen et al. 1984, Salminen \& Hartikainen 1985, Saarnisto \& Taipale 1984). In the fine fraction, trace metals are generally interpreted as be- ing derived from primary sulphide minerals, but they could also be trapped in clay minerals and Fe precipitates during pre-till bedrock weathering and weathering of the till (Shilts 1973, Peuraniemi 1982, Nikkarinen et al. 1984, Peuraniemi 1990). An increase in trace element contents with a reduction in grain size has been reported in many studies (Eriksson 1973, Toverud 1974, Äyräs 1977, Shilts 1980, Rencz \& Shilts 1980 Peuraniemi 1982, Nikkarinen et al. 1984).

Most previous studies have emphasized the mineralogical composition of different grain-size fractions and the distance of glacial transport of these fractions (Dreimanis \& Vagners $1971 \mathrm{a}$ and 1971 b, Linden 1975, Perttunen 1977, Peuranie-

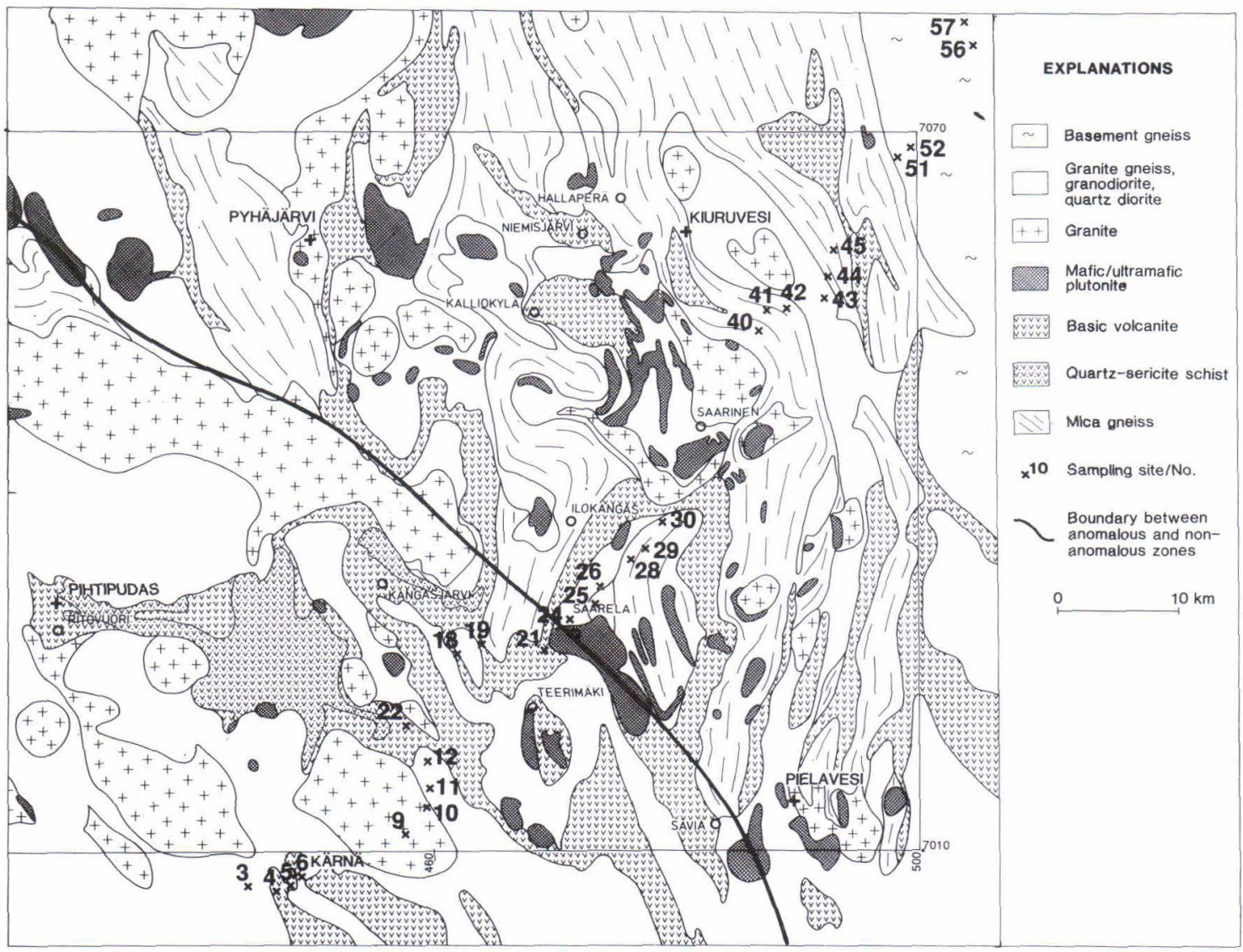

Fig. 1. Map of the bedrock geology of the study area in central Finland. The sampling sites of the composite rock samples are also marked. 
mi 1982, Nevalainen 1983). However, few studies deal with the physical and mineralogical properties of the fine fraction of till and their relationship to anomalously high trace metal contents on a regional scale (Mäkinen 1992, cf. Lintinen 1989).

This paper examines the relationship between mineralogy and the physico-chemical properties of till in the Raahe-Ladoga metallogenic belt in central Finland. In previous studies of that area, an abrupt change in element concentrations ranging from high in an anomalous zone (NE) to low in a non-anomalous zone (SW) has been attributed to co-existing glacigenic and bedrock features separated by fault zones (Kuosmanen 1988). According to Glumoff and Nikkarinen (1991), the lithological composition of bedrock is the dominant factor affecting on the chemical composition of the heavy mineral fraction (0.06-2 $\mathrm{mm}$ grain size) in tills of that area.

Attention is drawn to the mineralogical differences between the anomalous zone with high metal contents and the non-anomalous zone, and their relation to the physical properties of the fine fraction of till in both zones. Till samples for this study were taken from the surface layers of a till bed $(1-3 \mathrm{~m})$ as were the samples for the Geochemical Atlas of Finland (Koljonen et al. 1989), and not from deeper layers near the bedrock. The mineralogical and chemical relations of till to bedrock geochemistry were studied with samples of representative rock types and composite samples of weathered bedrock from the anomalous and non-anomalous zones.

\section{General geology of the study area}

\section{Bedrock geology}

The study area is made up of Early Proterozoic Svecofennian Supracrustal rocks between the Granitoid Batholith Complex of Central Finland and the Archaean Basement Gneiss Complex (Fig. 1) (Kuosmanen 1988). The southwestern part is dominated by granites, granodiorites, quartz diorites and quartz-sericite schists. Basic volcanics mainly exist between Kangasjärvi and Säviä, and north of Pihtipudas.

The northeastern part is characterized by an abundance of mica schists and basic volcanics. The border between Archean and Proterozoic is in northeastern part of the study area, and the basement gneiss represents the Archean formations. Granites and granitoids occur in minor amounts and Archaean gneisses predominate (Fig. 1).

Most of the known massive pyrite $-\mathrm{Cu}-\mathrm{Zn}$ sulphide occurrences lie in the volcanogenicsedimentary zone extending from Pyhäsalmi via Kalliokylä to Säviä. Typical of this zone is the occurrence of cordierite-anthophyllite-garnet rocks intercalated with schists. Another orepotential belt follows the zone of basic intrusive rocks along the line Säviä-Saarela-Saarinen-Kiuruvesi (Nikander 1988). The ore deposits and occurrences are part of the Raahe-Ladoga metallogenic belt (Kahma 1973).

\section{Quaternary geology}

The study area, which lies in the KiuruvesiVieremä region of central Finland, is divided into two Quaternary geological units (Salonen et al. 1988). The southwestern part of the area is the extensive Keitele drumlin field; the northeastern part of the area is morainal topography, where glacial erosion was weaker than in the drumlin area and weathered bedrock is encountered at numerous sites (Fig. 2). These two units are separated from each other by a northeast-trending esker system (Fig. 2). It has been suggested that the esker system forms an interlobate moraine between two glacial lobes (Punkari 1980, Ekdahl 1982).

Two till beds, presumably of different age, has been observed in the both areas of the low and high element concentrations (Hirvas \& Nenonen 1987, Ekdahl 1982). The bulk of the study area is covered by the younger till. The Keitele drum- 
lin field was formed during the deposition of this till, which is loose and sandy and brown in colour. In the drumlin field, which corresponds to the low elemental abundance, the younger till is often the only till unit.

The lowest till unit dark grey or bluish in colour, occurs more extensively in the passive ice than drumlin areas. The clay content of this older till is $18 \%$ in contrast to that of the younger sandy till, in which it is $2 \%$ (Hirvas 1980). It has been suggested that the older till unit occurs only in areas protected from the destructive action of younger ice movements (Salonen et al. 1988). This till is characterized by pollen flora of the Eem interglacial, indicating that interglacial sedi- ments were mixed with the lower till at an early stage of the Weichsel glaciation (cf. Rainio \& Lahermo 1976, Nurmi 1977, Iisalo 1992).

\section{Materials and methods}

\section{Sampling}

Twenty-one composite till samples were collected from a study line across the Raahe-Ladoga metallogenic belt in central Finland (Fig. 2). The distance between sampling sites along the line was from 3 to $10 \mathrm{~km}$. Subsamples were taken with a spade from road cuttings. The average depth

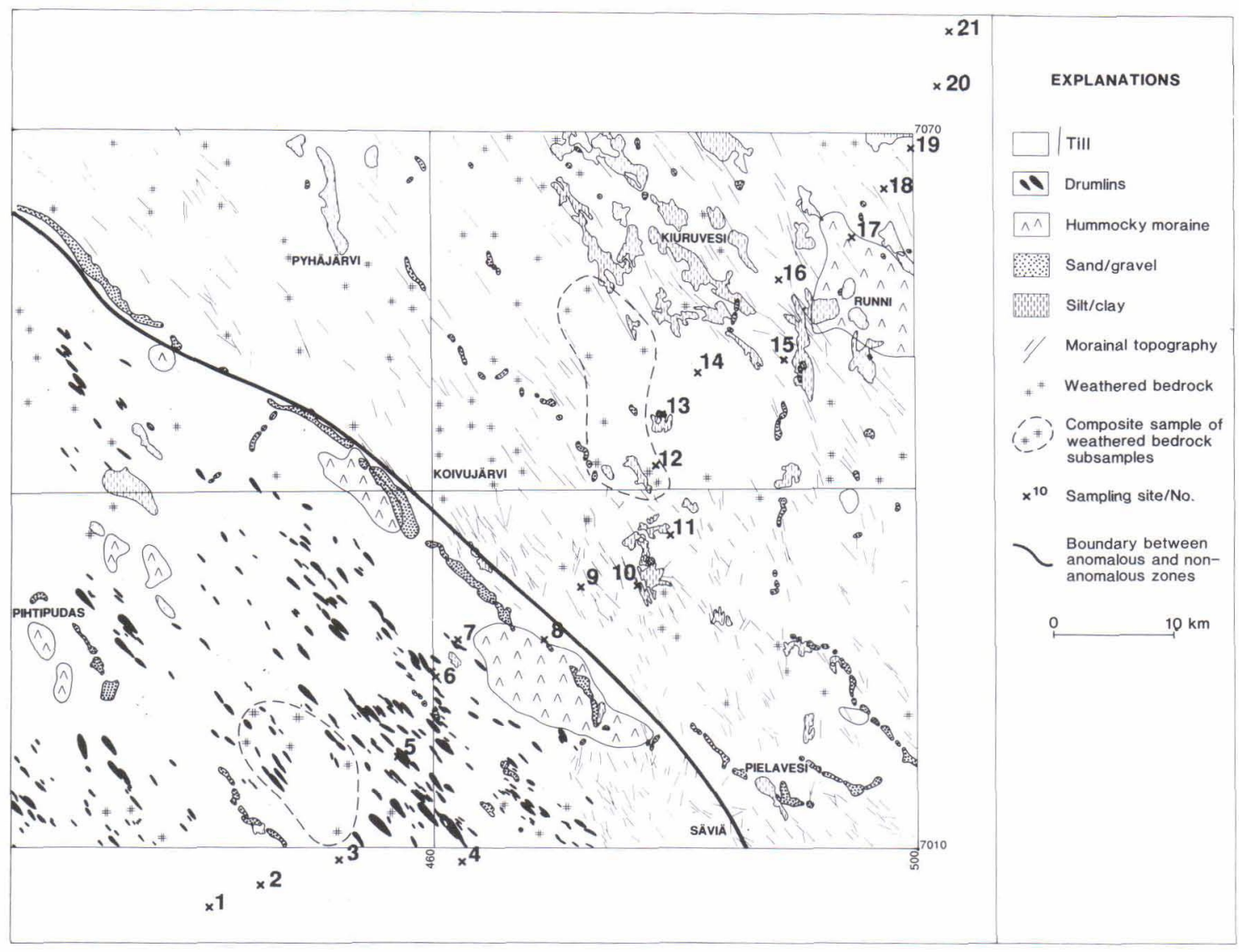

Fig. 2. Map of the Quaternary geology of the study area in central Finland. The sampling sites of till and the sampling area of the composite samples of weathered bedrock are also marked. 
of the till layers sampled in the road cutting trenches was $1-3 \mathrm{~m}$, but the sampling depth in the bottom of the road cuttings as measured from the uncovered surface, was less than $50 \mathrm{~cm}$. Three to five subsamples taken 1 to $10 \mathrm{~m}$ apart were combined into one composite sample for each sampling site. The volume of the composite sample was 4 liters. Samples No. $1-8$ were taken from the non-anomalous till zone, and samples No. 9-21 from the anomalous zone (Fig. 2). In the section on mineralogy samples of the anomalous zone is further divided into two subzones: anomalous I (Nos. 9-15) and anomalous II (Nos. 17-21).

Unweathered bedrock samples were collected with a field hammer from 28 outcrops (Fig. 1); 14 of them were granitoids and 14 mica gneisses. Chemical analyses of the granitoids were made on four composite samples of granite rocks and four composite samples of granodiorites from both the non-anomalous and anomalous zones corresponding to till geochemistry (Fig. 1). Five samples of mica gneiss were taken from the anomalous zone and nine from the non-anomalous zone. Each of the sample types was a composite sample of five subsamples weighing approximately $5 \mathrm{~kg}$. The subsamples for one composite sample were collected from the same outcrop with an average surface area of $1500 \mathrm{~m}^{2}$.

Two composite samples of the weathered bedrock used for the mineralogical studies were made by combining six subsamples collected from the non-anomalous zone, and eight from the anomalous zone (Fig. 1). The subsamples were taken in the course of the regional geochemical till mapping conducted by the Geological Survey of Finland (GSF) in 1988, in which the sampling density was one sample per $4 \mathrm{~km}^{2}$. The samples of weathered crust were taken with a percussion drill under the till beds.

\section{Measurements of physical properties}

The grain size distribution was determined from $100 \mathrm{~g}$ of till samples. The grain size distri- bution of the $<0.06 \mathrm{~mm}$ fraction was analysed with the areometrical method, and that of the $>0.06 \mathrm{~mm}$ fraction by dry sieving. The determinations were made at the Soil Laboratory of the GSF in Kuopio.

The specific surface area was measured with a Micromeritic Flow Sorb II 2300 at the Soil Laboratory of the GSF in Espoo. The gas was a mixture of $30 \% \mathrm{~N}$ and $70 \% \mathrm{He}$. The $<0.06$ $\mathrm{mm}$ fraction samples used in the measurements weighed $0.6-1.3 \mathrm{~g}$. The unit weight of the same fraction was measured according to the method described by Mäkinen (1992).

\section{Chemical analyses of the fine fraction of till}

All the chemical analyses were made on the silt and clay fraction, that is the less than $0.06 \mathrm{~mm}$. Sample No. 6 from the non-anomalous zone was not included because it did not contain enough fine fraction for several chemical analyses.

The main and trace element concentrations of the fine fraction were analysed with a hot aqua regia leach method modified by the Chemical Laboratory of the GSF in Kuopio (see Räisänen et al. 1992). A 3:1 mixture of hydrochloric and nitric acids is commonly used for analyzing till samples in the GSF's geochemical mapping programme. Concentrations of $\mathrm{Al}, \mathrm{Fe}, \mathrm{Ca}, \mathrm{Mg}, \mathrm{K}$, $\mathrm{Na}$ and trace metals $(\mathrm{Ba}, \mathrm{Co}, \mathrm{Cu}, \mathrm{Mn}, \mathrm{Ni}, \mathrm{Pb}$, $\mathrm{Zn})$ were measured from the leachates with atomic absorption spectrophotometry (AAS).

The solubility of $\mathrm{Ca}, \mathrm{Mg}, \mathrm{K}, \mathrm{Na}, \mathrm{Al}, \mathrm{Fe}$ was determined with the acid neutralizing capacity (ANC) method (Räisänen 1989). Only two types of extraction were used: a $0.025 \mathrm{M} \mathrm{NH}_{4} \mathrm{NO}_{3}$ extraction and an acidic salt extraction, that is, $\mathrm{ANC}_{\mathrm{pH} 2.3-2.4}$ extraction, where the subindex refers to the $\mathrm{pH}$ of the $\mathrm{NH}_{4} \mathrm{NO}_{3}$ solution after the addition of $0.1 \mathrm{~N} \mathrm{H}_{2} \mathrm{SO}_{4}$ solution. The soil $\mathrm{pH}$ was measured as the $\mathrm{pH}$ of the supernatant after the $\mathrm{NH}_{4} \mathrm{NO}_{3}$ extraction. The soluble cations in the supernatant were measured with AAS at the Chemical Laboratory of the GSF in Kuopio. 
Iron, aluminium and some trace metals (Co, $\mathrm{Cu}, \mathrm{Ni}, \mathrm{Mn}, \mathrm{Zn}$ ) bound to inorganic precipitates were determined with the ammonium oxalate extraction at $\mathrm{pH}$ 3.0, modified as in Räisänen et al. (1992). The concentrations of trace metals, Al and $\mathrm{Fe}$ in the supernatant were measured with AAS at the Chemical Laboratory of the GSF in Kuopio.

\section{Chemical analyses of bedrock samples}

The bedrock samples were crushed in a jaw crusher to a grain size of $<5-6 \mathrm{~mm}$. $60 \mathrm{~g}$ of crushed sample was ground in a wolfram-carbide pan, and $7 \mathrm{~g}$ of the powder was used for the chemical analysis. Total element concentrations were measured with XRF at the Chemical Laboratory of the GSF in Otaniemi.

\section{$X$-ray diffraction analysis of the fine fraction of till}

\section{Treatments and identification}

The sample preparation for XRD analysis was modified to use minor portions of sieved samples of the $<0.06 \mathrm{~mm}$ grain-size as used in chemical analyses. Oriented aggregates from this fraction were made with the sedimentation technique, which included pipette sampling from suspensions of unextracted and extracted samples (Whittig and Allardice 1986). Because of the low clay content $(<5 \%)$ of the samples from the nonanomalous zone, the grain-size of all oriented aggregates was in this study coarser than generally used in clay mineral studies. The average grain size selected here was either $<0.04 \mathrm{~mm}$ or $<0.05$ $\mathrm{mm}$ (sedimentation time of $1-2 \mathrm{~min}$ ). Aggregates of the comparative $<0.02 \mathrm{~mm}$ fraction were examined from only a few samples with higher clay contents.

Air-dried oriented aggregates of 20 samples (excluding sample No, 6) were made from subsamples (a) suspended with ionized water and (b) leached with hot aqua regia. The digestion residues were washed with ionized water, and then suspended once more in deionized water before the pipette sampling. Moreover, clay minerals were studied doser after several extractions and heat treatments from 12 samples selected from the anomalous I (3 samples) and II (5 samples) zones and the non-anomalous (4 samples) zone.

In the clay mineral study, 'free' aluminium and iron hydroxides from edges and interlayers of clay minerals were extracted with the acid oxalate instead of the dithionite-citrate method generally used (Mehra and Jackson 1960, see also Dixon \& Weed 1977). The acid oxalate extraction was selected in this context because of the low content of iron precipitates and its easier procedure. The $\mathrm{ANC}_{\mathrm{pH} 2.3-2.4}$ extraction was modified here to examine the lability of Al-hydroxy interlayers. The comparative procedure to this extraction was $\mathrm{K}$ saturation including $1 \mathrm{M}$ $\mathrm{KCl}$ extraction. The identification method of the interlayered minerals and pure vermiculite usually employed requires $\mathrm{K}$-saturation with heat treatments (Douglas 1977, Wilson 1987).

Comparative procedures for the identification of clay minerals were following: (1) the $\mathrm{ANC}_{\mathrm{pH} 2.3-2.4}$ extracted, (2) $\mathrm{ANC}_{\mathrm{pH} 2.3-2.4}$ extracted and heated at $200{ }^{\circ} \mathrm{C}$ (stayed for $30 \mathrm{~min}$ ), (3) $\mathrm{ANC}_{\mathrm{pH} 2.3-2.4}$ extracted and heated at $550^{\circ} \mathrm{C}$ (stayed for $10 \mathrm{~min}$ ), (4) $\mathrm{K}$ saturated, (5) $\mathrm{K}$ saturated and heated at $200{ }^{\circ} \mathrm{C}$ (for $30 \mathrm{~min}$ ), (6) $\mathrm{K}$ saturated and heated at $550^{\circ} \mathrm{C}$ (for $10 \mathrm{~min}$ ), (7) acid oxalate extracted, (8) acid oxalate extracted and heated at $200{ }^{\circ} \mathrm{C}$ (for $30 \mathrm{~min}$ ), and (9) acid oxalate extracted and heated at $550{ }^{\circ} \mathrm{C}$ (for 10 min). The swelling properties of clay minerals were studied with ethylene glycol solvation. One or two drops of ethylene glycol were introduced onto air-dried aggregate made from a subsample extracted with the $\mathrm{ANC}_{\mathrm{pH} 2.3-2.4}$ solution. Procedures of the acid oxalate and $\mathrm{ANC}_{\mathrm{pH} 2.3-2.4}$ extractions were described in the section of the chemical analysis.

XRD patterns of all oriented aggregates were run at a scanning rate of $1^{\circ}$ per min using a Phillips diffractometer and $\mathrm{Ni}$-filtered $\mathrm{Cu} \alpha$ radiation. The XRD analyses were made at the GSF's Mineralogical Laboratory in Kuopio. The XRD- 
Table 1. The strongest d-values of the main minerals commonly found in till samples and their $\mathrm{K}$ constants determined by P. Kallio at the Mineralogical Laboratory of the Geological Survey of Finland in Kuopio.

\begin{tabular}{lrc}
\hline Mineral & d-value & K \\
\hline Quartz & $4.25 \AA$ & 3.0 \\
K-feldspar & $3.24 \AA$ & 4.0 \\
Plagioclase & $3.19 \AA$ & 4.0 \\
Hornblende & $8.4 \AA$ & 1.5 \\
Mica & $10.0 \AA$ & 4.0 \\
Chlorite & $14 \AA$ & 4.0 \\
\hline
\end{tabular}

analysis handbooks edited by Thorez (1975), Dixon \& Weed (1977) and Brindley \& Brown (1980) were used as an aid in mineral identifications. Kaolinite was identified on the basis of its instability at $550^{\circ} \mathrm{C}$ (Brindley 1961).

\section{Quantitative determination}

The semiquantitative mineral abundance of the fine fraction was determined with XRD using sieved samples of random orientation. Samples of the $<0.06 \mathrm{~mm}$ grain size were spread onto glass slides without further grinding. XRD patterns were run at a scanning rate of $1^{\circ}$ per min using a Phillips diffractometer at the GFS's Mineralogical Laboratory in Kuopio. The mineral composition was determined with the external intensity ratio technique described by Pawloski (1985). The highest integrated intensity peak of each mineral to be quantified was used with the highest integrated intensity peak of quartz to calculate the ratio:

$$
\frac{X_{\text {mineral }}}{X_{\text {quartz }}}=K \frac{I_{\text {mineral }}}{I_{\text {quartz }}} \text {, where }
$$

$\mathrm{X}_{\text {mineral }}=$ weight of mineral, $\mathrm{X}_{\text {quartz }}=$ weight of quartz, $\mathrm{K}=$ slope of calibration curve for the mineral, $\mathrm{I}_{\text {mineral }}=$ integrated intensity of the highest peak of the mineral in the XRD pattern, and $I_{\text {quartz }}=$ integrated intensity of the highest peak of the quartz XRD pattern.
The abundances of quartz, K-feldspar, plagioclase, hornblende, micas and the clay mineral group with the $14 \AA$ spacing were calculated semiquantitatively using the intensities of the strongest d-values and the constants $(\mathrm{K})$ presented in Table 1. The constant of chlorite in Table 1 was used for the clay mineral group with the $14 \AA$ spacing, which includes chlorite and mixed-layer clay minerals of chlorite and vermiculite.

The di- and trioctahedral micas were identified and estimated semiquantitatively from oriented aggregates on the basis of the reduced intensity of the $10 \AA$ peak, and the increased intensity of the $5 \AA$ peak after aqua regia digestion (Fig. 3). If weak or totally absent, the $5 \AA$ peak refers to the presence of trioctahedral rather than dioctahedral mica (Wilson 1987, Fanning \& Keramidas 1977, Soveri \& Hyyppä 1966, Sippola 1974). The 060 spacing characteristic of the dioctahedral forms $(1.49-1.50 \AA$ ), which is generally used to distinguish the dioctahedral from the trioctahedral mica group (spacings between 1.52 and $1.54 \AA$ ), was occasionally observed before or after the acid digestion. However, the $1.53 \AA$ reflection attributed to phlogopite in this study occurred together with the $1.54 \AA$ diffraction maximum of quartz in both cases (Fig. 3). The abundance of the chloritic component in mixedlayer clay minerals was estimated from the residual intensity of the $14 \AA$ peak after the oriented aggregate made from a sample extracted with the acid oxalate had been heated at $550^{\circ} \mathrm{C}$.

\section{X-ray diffraction analysis of composite} samples of weathered bedrock

Subsamples of weathered bedrock from areas of the non-anomalous and anomalous zones were combined into two samples by sieving the $<0.06$ $\mathrm{mm}$ fraction. Oriented aggregates of these two composite samples were examined for clay minerals only. Before the XRD analysis, the sieved samples were treated as follows: 1) air-dried, 2) K-saturated with $1 \mathrm{M} \mathrm{KCl}, 3) \mathrm{ANC}_{\mathrm{pH} 2.3-2.4}$ extracted, 4) $\mathrm{ANC}_{\mathrm{pH} 2.3-2.4}$ extracted and ethylene glycol solvated, 5) $\mathrm{ANC}_{\mathrm{pH} 2.3-2.4}$ extracted and 

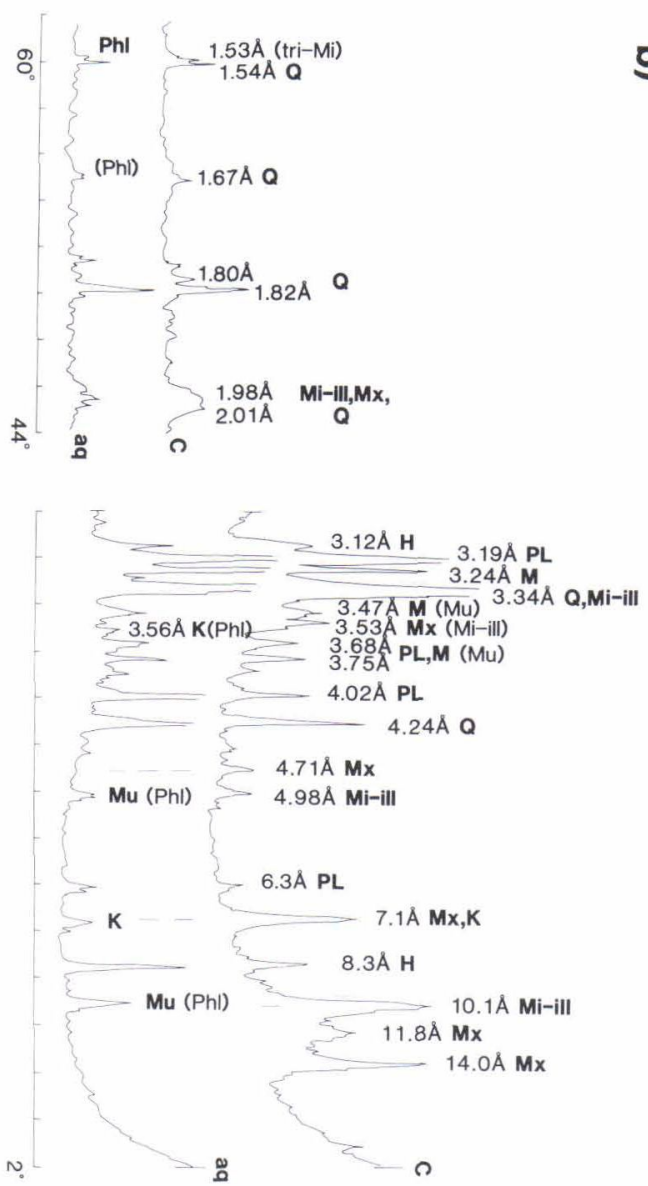
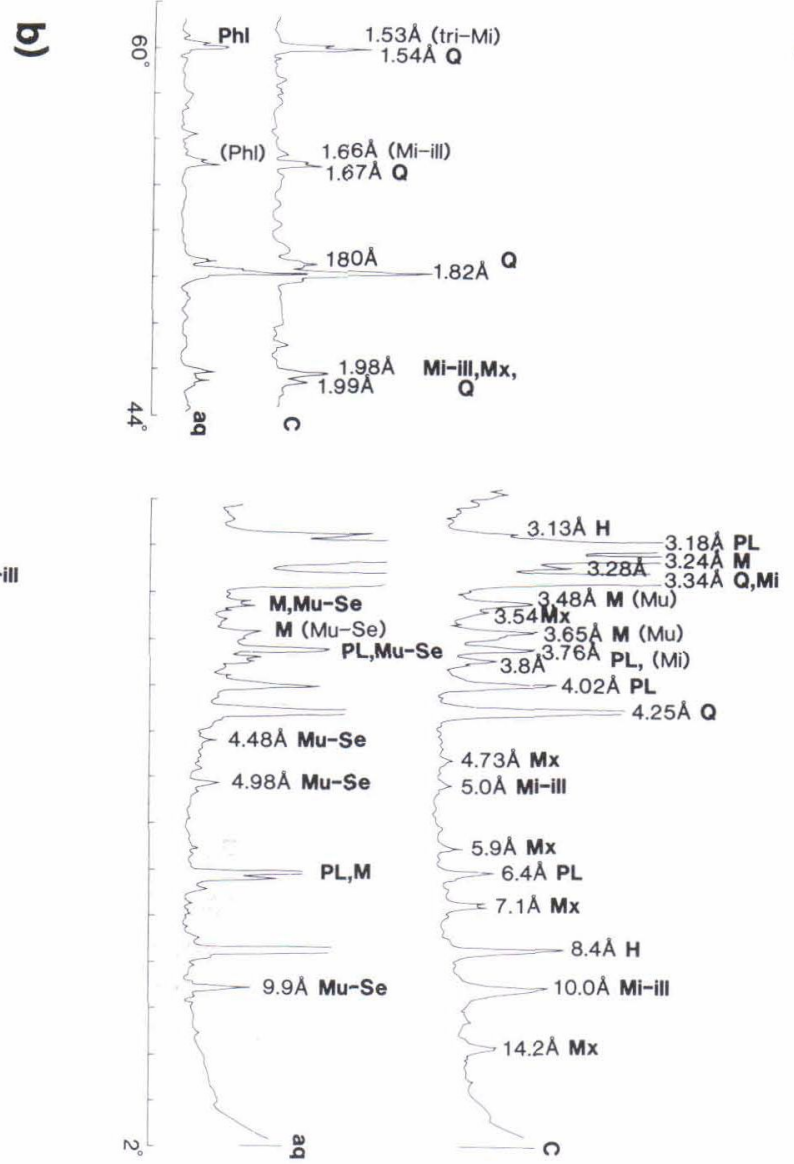

Fig. 3. X-ray diffraction traces of the oriented aggregates of (a) sample No. 1 from the non-anomalous zone and (b) sample No. 9 from the anomalous zone before and after the treatment with hot aqua regia. Treatments: $\mathrm{C}=$ air $d r i e d, a q=a q u a$ regia leached; Identified minerals: $\mathrm{Mx}=$ mixed-layer clay mineral, $\mathrm{Mi}-\mathrm{ill}=$ illitic mica, $\mathrm{H}=$ hornblende, $\mathrm{PL}=$ plagioclase, $\mathrm{Q}=$ quartz, $\mathrm{M}=$ microcline ( $\mathrm{K}$-feldspar), $\mathrm{Mu}=$ muscovite, $\mathrm{Se}=$ sericite, $\mathrm{Phl}=$ phlogopite, $\mathrm{K}=$ kaolinite, tri-Mi = trioctahedral mica.

heated at $200^{\circ} \mathrm{C}$, and 6) $\mathrm{ANC}_{\mathrm{pH} 2.3-2.4}$ extracted and heated at $550^{\circ} \mathrm{C}$. Like the till samples, the grain size of the weathered rock samples used in the XRD analysis was either $<0.04$ or $<0.05 \mathrm{~mm}$.

\section{Statistical treatment of data}

The main aim of the chemical data processing was to present the variables in graphical form. Multivariate methods were used to establish the relationships between the chemical, mineralogical and physical properties of the fine fraction of till. Factor analysis and multidimensional scaling were based on rank correlation matrix of the variables.

The statistical significance of the chemical differences between the bedrock samples from the anomalous zone and those from the nonanomalous zone was tested with the non-parametric Mann-Whitney Test.

The results were graphically presented with the 
Table 2. The proportion ( $\%$ ) of grain sizes $<0.06 \mathrm{~mm}$ and $<0.002 \mathrm{~mm}$ (clay content), specific surface area, and unit weight in samples from the study line in central Finland.

\begin{tabular}{|c|c|c|c|c|c|c|c|c|}
\hline \multirow{2}{*}{$\begin{array}{l}\text { Sample } \\
1\end{array}$} & \multicolumn{2}{|c|}{$\phi<0.06 \mathrm{~mm}$} & \multicolumn{2}{|c|}{$\phi<0.002 \mathrm{~mm}$} & \multicolumn{2}{|c|}{$\begin{array}{l}\text { Specific surface } \\
\text { area } \mathrm{m}^{2} / \mathrm{g}\end{array}$} & \multicolumn{2}{|c|}{$\begin{array}{l}\text { Unit weight } \\
\text { values } \mathrm{g} / \mathrm{ml}\end{array}$} \\
\hline & & 39.9 & & 1.44 & & 1.30 & & 1.83 \\
\hline 2 & & 54.6 & & 2.50 & & 1.42 & & 1.81 \\
\hline 3 & & 40.3 & & 1.70 & & 1.26 & & 1.76 \\
\hline 4 & $\mathrm{M}=32.3$ & 31.2 & $\mathrm{M}=1.70$ & 3.83 & $\mathrm{M}=1.58$ & 4.02 & $\mathrm{M}=1.80$ & 1.61 \\
\hline 5 & $X=36.7$ & 31.7 & $X=2.23$ & 1.70 & $X=2.31$ & 1.58 & $X=1.74$ & 1.82 \\
\hline 7 & & 32.3 & & 2.76 & & 2.84 & & 1.80 \\
\hline 8 & & 26.7 & & 1.70 & & 3.73 & & 1.56 \\
\hline 9 & & 48.4 & & 15.3 & & 15.3 & & 1.34 \\
\hline 10 & & 60.1 & & 18.5 & & 18.8 & & 1.49 \\
\hline 11 & & 57.4 & & 15.9 & & 20.8 & & 1.54 \\
\hline 12 & & 34.8 & & 7.73 & & 8.79 & & 1.44 \\
\hline 13 & & 41.4 & & 9.89 & & 16.3 & & 1.59 \\
\hline 14 & $M=46.4$ & 50.2 & $M=9.89$ & 11.5 & $M=14.5$ & 21.1 & $\mathrm{M}=1.56$ & 1.56 \\
\hline 15 & $X=48.8$ & 41.3 & $X=10.8$ & 5.82 & $X=12.5$ & 6.78 & $X=1.53$ & 1.60 \\
\hline 16 & & 53.7 & & 2.78 & & 1.51 & & 1.76 \\
\hline 17 & & 44.2 & & 9.89 & & 14.0 & & 1.69 \\
\hline 18 & & 34.3 & & 2.83 & & 3.90 & & 1.52 \\
\hline 19 & & 77.1 & & 24.9 & & 7.44 & & 1.23 \\
\hline 20 & & 45.7 & & 8.60 & & 15.4 & & 1.56 \\
\hline 21 & & 46.4 & & 6.69 & & - & & 1.61 \\
\hline
\end{tabular}

Chart Microsoft Program. The multivariate processing of the data was done with SPSSX software.

\section{Results and discussion}

\section{Grain size distribution of till}

The median values of the abundance of fine fractions of till are only slightly higher in the anomalous zone $(32.3 \%)$ than in the non-anomalous zone (46.4\%) (Table 2). The abundance of the $<0.002 \mathrm{~mm}$ fraction, corresponding to the grain size of clay, is higher in the anomalous zone than in the non-anomalous zone by a factor of 5.8 based on the median values.

The abundances of the clay and fine fractions show a positive correlation with the specific surface values (Tables 2, and 5 b). This is understandable as $75-95 \%$ of the surface area of the sample is due to the fine fraction of till (Niemi- nen 1985). There is also a clear positive correlation between the clay content of soils and porosity (Farrar \& Coleman 1967). In the non-anomalous zone, the median value of the specific surface area is 1.58 and in the anomalous zone 14.5 (Table 2).

The sampling line was later extended over the northeastern side of the anomalous zone to the non-anomalous zone. Preliminary results show that the median values of the abundance of the clay fraction $\left(M_{n=6}=8.6 \%\right)$ in the anomalous zone are higher than those in the non-anomalous zone in the northeast $\left(M_{n=9}=2.8 \%\right)$ by a factor of 3.1 .

\section{Chemical composition of bedrock samples}

The chemical compositions of granite and granodiorite in the anomalous and non-anomalous zones differed significantly from each other only in potassium and sodium abundances. The median value of sodium was lower and that of 
Table 3 a. Median, arithmetic mean, maximum, minimum and standard deviation values of the granites and granodiorites in the (1) non-anomalous and (2) anomalous zones. The data are from four granite samples (Nos. 9, 10, 12, 22) and three granodiorite samples (Nos. 3, 11, 18) in the non-anomalous zone and four granite samples (Nos. 51, 52, 56, 57) and three granodiorite samples (Nos. 26, 30,44) in the anomalous zone (see Fig. 2). The anomalous zones were determined from the till geochemistry (see text).

\begin{tabular}{|c|c|c|c|c|c|c|c|c|c|c|}
\hline Element & $\begin{array}{c}\text { Median } \\
1\end{array}$ & $\underset{2}{\text { Median }}$ & $\begin{array}{c}\text { Mean } \\
1\end{array}$ & $\begin{array}{c}\text { Mean } \\
2\end{array}$ & $\underset{1}{\operatorname{Max} .}$ & $\underset{2}{\operatorname{Max} .}$ & $\underset{1}{\operatorname{Min} .}$ & $\underset{2}{\operatorname{Min} .}$ & $\begin{array}{c}\text { St. dev. } \\
1\end{array}$ & $\begin{array}{c}\text { St. dev. } \\
2\end{array}$ \\
\hline $\mathrm{Al}_{2} \mathrm{O}_{3} \%$ & 14.2 & 15.2 & 14.4 & 15.2 & 15.9 & 16.4 & 13.5 & 13.7 & 0.79 & 0.93 \\
\hline $\mathrm{Fe}_{2} \mathrm{O}_{3} \%$ & 3.10 & 3.27 & 3.86 & 4.06 & 7.27 & 7.67 & 1.83 & 0.86 & 2.08 & 2.64 \\
\hline $\mathrm{CaO} \%$ & 2.31 & 2.72 & 2.58 & 3.45 & 4.60 & 6.07 & 1.36 & 2.13 & 1.25 & 1.63 \\
\hline $\mathrm{MgO} \%$ & 0.79 & 0.90 & 0.76 & 1.55 & 1.28 & 4.10 & 0.31 & 0.31 & 0.34 & 1.45 \\
\hline $\mathrm{K}_{2} \mathrm{O} \%$ & 3.41 & 2.33 & 3.29 & 2.33 & 4.73 & 3.32 & 1.10 & 0.96 & 1.09 & 0.76 \\
\hline $\mathrm{Na}_{2} \mathrm{O} \%$ & 3.89 & 4.50 & 3.78 & 4.40 & 4.03 & 4.97 & 3.23 & 3.60 & 0.28 & 0.43 \\
\hline $\mathrm{MnO} \%$ & 0.07 & 0.07 & 0.09 & 0.07 & 0.16 & 0.11 & 0.04 & 0.04 & 0.04 & 0.03 \\
\hline $\mathrm{Ni} \mathrm{ppm}$ & 11.0 & 11.0 & 10.1 & 19.6 & 12.0 & 58.0 & 6.00 & 8.00 & 2.12 & 18.0 \\
\hline $\mathrm{Cu} \mathrm{ppm}$ & 0.00 & 5.00 & 3.43 & 8.00 & 18.0 & 26.0 & 0.00 & 0.00 & 6.80 & 10.4 \\
\hline $\mathrm{Zn} \mathrm{ppm}$ & 61.0 & 77.0 & 76.6 & 78.6 & 134. & 132. & 52.0 & 25.0 & 29.4 & 39.3 \\
\hline $\mathrm{Cr}$ ppm & 26.0 & 27.0 & 24.0 & 47.1 & 28.0 & 111. & 18.0 & 18.0 & 3.70 & 40.2 \\
\hline
\end{tabular}

a)

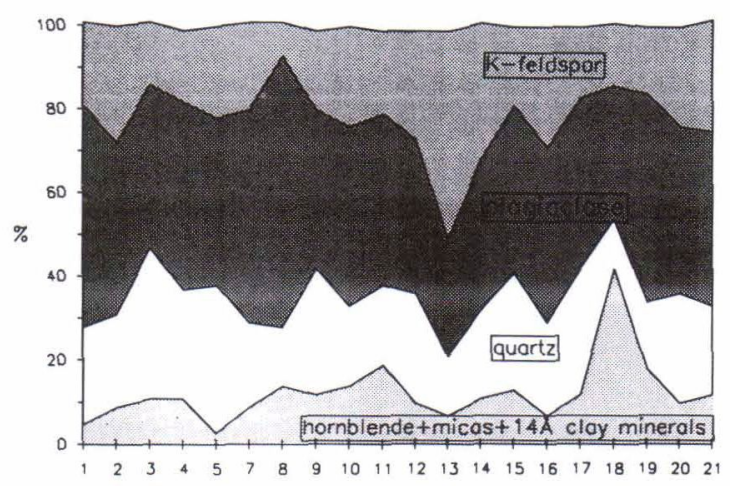

b)

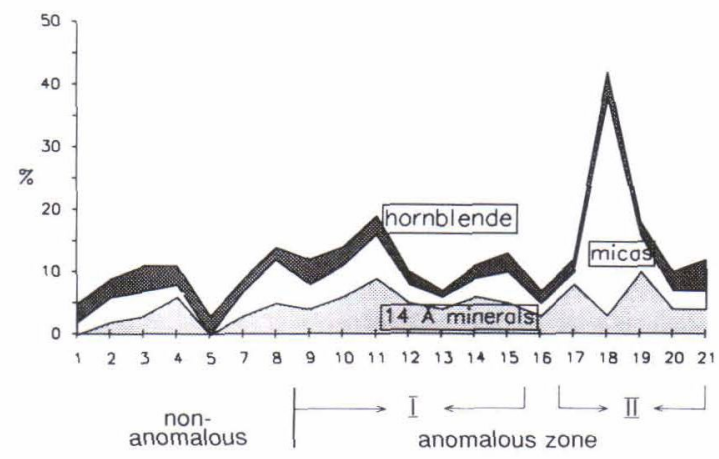

Fig. 4. Mineralogical distribution of (a) the main silicates, quartz, plagioclase and $\mathrm{K}$-feldspar, and (b) hornblende, micas and the $14 \AA$ mineral group along the study line in central Finland. potassium higher in the non-anomalous zone than in the anomalous zone (Table 3 a).

The concentrations of $\mathrm{Fe}, \mathrm{Al}, \mathrm{Mn}, \mathrm{Ca}, \mathrm{K}, \mathrm{Zn}$ and $\mathrm{Ni}$ in mica gneisses showed statistically significant differences between the anomalous and non-anomalous zones (Table $3 \mathrm{~b}$ ). The nickel concentrations, in particular, were clearly higher in the anomalous than in the non-anomalous zone. The zinc concentrations were about the same in both areas (Fig. 1).

It is difficult to assess the average chemical composition of till from the rock samples, because the proportions of rock types vary markedly between the zones. For example, the abundance of mica gneisses in the bedrock of the anomalous zone is very low (Fig. 1), and yet the importance of mica schists and micaceous rocks as anomaly sources is emphasized in analytical data based on partial leach.

\section{Mineralogy of the fine fraction of till}

\section{Main silicates}

The main silicate minerals in the fine fraction of till on the study line are plagioclase, quartz and potassium feldspar (Fig. 4 a). The plagioclase was a Na-rich type (albite-oligoclase) rather than 
Table 3 b. Median, arithmetic mean, maximum, minimum and standard deviation values in the (1) non-anomalous and (2) anomalous zones. The data are from five mica schist samples from the non-anomalous zone (Nos. 4, 5, 6, 19, 21) and nine mica schist samples from the anomalous zone (Nos. 24, 25, 28, 29, 40, 41, 42, 43, 45) (see Fig. 2). The anomalous zones were determined from the till geochemistry (see text).

\begin{tabular}{|c|c|c|c|c|c|c|c|c|c|c|}
\hline Element & $\begin{array}{c}\text { Median } \\
1\end{array}$ & $\begin{array}{c}\text { Median } \\
2\end{array}$ & $\begin{array}{c}\text { Mean } \\
1\end{array}$ & $\begin{array}{c}\text { Mean } \\
2\end{array}$ & $\begin{array}{c}\text { Max. } \\
1\end{array}$ & $\underset{2}{\operatorname{Max} .}$ & $\begin{array}{c}\text { Min. } \\
1\end{array}$ & $\begin{array}{c}\text { Min. } \\
2\end{array}$ & $\begin{array}{c}\text { St. dev. } \\
1\end{array}$ & $\begin{array}{c}\text { St. dev. } \\
2\end{array}$ \\
\hline $\mathrm{Al}_{2} \mathrm{O}_{3} \%$ & 16.0 & 15.0 & 16.7 & 15.1 & 20.5 & 17.8 & 14.8 & 12.8 & 2.24 & 1.36 \\
\hline $\mathrm{Fe}_{2} \mathrm{O}_{3} \%$ & 8.03 & 5.92 & 8.44 & 5.63 & 11.7 & 8.50 & 7.20 & 1.68 & 1.84 & 2.21 \\
\hline $\mathrm{CaO} \%$ & 5.24 & 2.47 & 5.71 & 3.20 & 8.74 & 6.26 & 3.52 & 0.55 & 1.93 & 1.96 \\
\hline $\mathrm{MgO} \%$ & 2.14 & 2.99 & 2.46 & 2.70 & 3.73 & 3.71 & 1.26 & 1.24 & 1.10 & 0.76 \\
\hline $\mathrm{K}_{2} \mathrm{O} \%$ & 1.36 & 2.67 & 1.57 & 2.48 & 2.50 & 3.92 & 0.63 & 1.50 & 0.82 & 0.75 \\
\hline $\mathrm{Na}_{2} \mathrm{O} \%$ & 3.07 & 3.74 & 3.17 & 3.50 & 3.98 & 4.49 & 2.36 & 1.66 & 0.66 & 0.04 \\
\hline $\mathrm{MnO} \%$ & 0.16 & 0.09 & 0.16 & 0.09 & 0.20 & 0.15 & 0.12 & 0.02 & 0.03 & 0.04 \\
\hline Ni ppm & 14.0 & 24.0 & 17.6 & 31.9 & 38.0 & 55.0 & 6.00 & 10.0 & 12.7 & 16.5 \\
\hline $\mathrm{Cu}$ ppm & 14.0 & 27.0 & 17.4 & 25.8 & 48.0 & 51.0 & 0.00 & 0.00 & 19.0 & 16.2 \\
\hline $\mathrm{Zn} \mathrm{ppm}$ & 124. & 101. & 126. & 96.9 & 147. & 124. & 94.0 & 58.0 & 21.2 & 19.7 \\
\hline Cr ppm & 38.0 & 74.0 & 55.2 & 80.0 & 149.0 & 137. & 150 & 170 & 54.5 & 40.5 \\
\hline
\end{tabular}

a Ca-rich one, as shown by its predominant reflections of $6.3-6.4 \AA, 4.02 \AA$ and $3.19 \AA$. The abundance of amphiboles, which were identified mainly as hornblende (Fig. 3), and that of the mica-clay mineral group account for less than $20 \%$ of the total (Fig. 4 b). The difference in the abundances of the main silicates between the anomalous and non-anomalous zones is not very marked as is seen in Fig. 4 a. There were a few exceptions in the mineral distribution: sample No. 5 was poor in micas and clay minerals, No. 8 was rich in plagioclase, No. 13 was rich in Kfeldspar, and No. 18 was rich in micas (Fig. 4).

According to the XRD analysis, the aqua regia leach did not dissolve feldspars, amphiboles or quartz in detectable amounts (Fig. 3). It did, however, intensify the peaks characteristic of these silicates in many samples, regardless of the sampling site. The intensities of these stable minerals might increase, because the very fine fraction was leached away. Otherwise, the increased sharpness of the diffraction peaks might be due to the etched surfaces from which the acid had leached impurities. It is, in this case, suggested that the elements leached from these silicates are bound to their broken surfaces. According to Foster (1971 and 1973), the extractability of metals from amphiboles can vary from under
$25 \%$ to $60 \%$. In the same study, the extractability of elements from quartz and feldspar was also low, depending on the grain size and lattice positions and bond strengths of the trace elements (cf. Fletcher 1981).

\section{Micas}

The abundance of the mica and clay mineral group was, on average, slightly higher in samples from the anomalous zone than in those from the non-anomalous zone (Fig. 4 b), but not as high as was expected on the basis of the distribution of the clay content and the main elements leached in aqua regia along the study line (Fig. 5). The proportion of micas ( $10 \AA$ ) relative to clay minerals of the $14 \AA$ spacing varies from sample to sample along the study line, but the estimated abundance of micas is lower in the anomalous than in the non-anomalous zone, as shown in Fig. 5. The only exceptionally high abundance of mica was observed in sample No. 18 (Fig. 4 b), which had a very low clay content (Table 2).

Both di- and trioctahedral micas occurred in slightly weathered forms in all the samples studied. The predominant dioctahedral mica type was muscovite or sericite (main peak at $9.9 \AA$ ). Trioctahedral micas were biotite and phlogopite 
(10.0-10.1 §). In untreated samples the diffraction line at $10 \AA$ was broad, extending from 10.0 $\AA$ to $10.3 \AA$, and was therefore attributed to illitic mica (Figs. 3, 6, 8). In this context, illitic mica is considered to be a mixed-layer mineral, either trioctahedral or dioctahedral. It contains variable amounts of a non-expanding illitic component, with mica as the major component.

According to a rough estimate based on the XRD analyses of oriented aggregates, dioctahedral illitic micas are the predominant mica group in the non-anomalous zone and trioctahedral (mainly biotite) in the anomalous zone. As shown by the study of Soveri and Hyyppä (1966), in Finland the predominant mica in the fine fraction of till is mainly a trioctahedral type, as it is also in the argillaceous sediments studied by Sippola (1974). Note, however, that the study of Soveri and Hyyppä (1966) included only a few till samples from the bedrock areas of southern and central Finland.

The abundance of trioctahedral phlogopite (Mg-rich) in relation to that of biotite (Fe-rich) varies in both areas. The reflection (1.53 $\AA$ ) characteristic of phlogopite was observed in every sample from the non-anomalous zone, except No. 16. It was recorded occasionally in the anomalous II zone but in the anomalous I zone it was absent only from sample No. 11 .

The hot aqua regia leach had different effects on different mica types. After the digestion, the intensity of the broad $10 \AA$ peak of illitic micas was reduced, whereas the intensity of the $5 \AA$ spacing characteristic of dioctahedral muscovite remained constant or was even increased (Figs. 3 and 6). The spacing between 4.47 and $4.49 \AA$

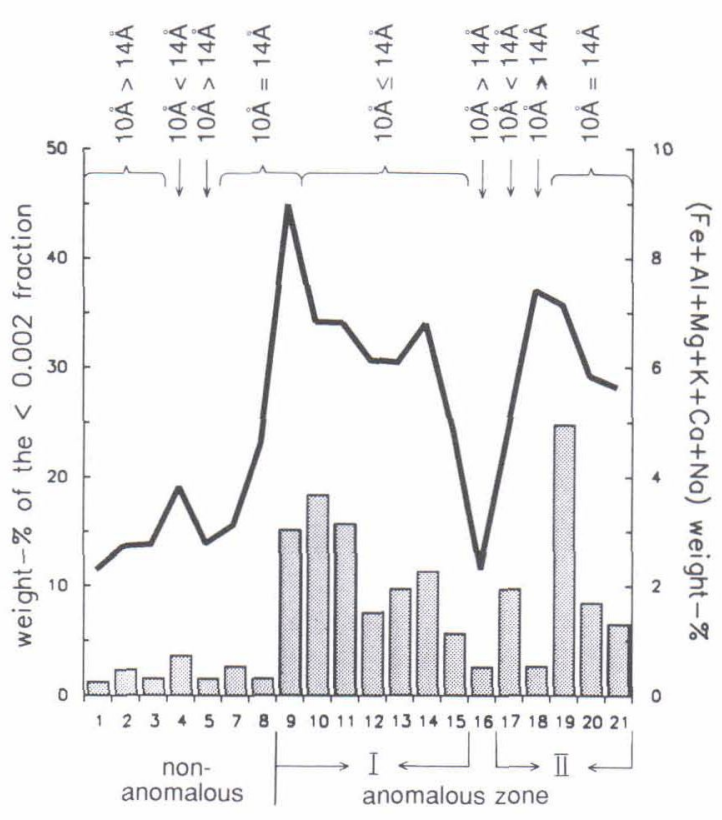

Fig. 5. Calculated total sum (black line) of the main elements ( $\mathrm{Al}, \mathrm{Fe}, \mathrm{Mg}, \mathrm{K}, \mathrm{Ca}, \mathrm{Na}$ ) soluble in hot aqua regia and the clay content (grey histograms) of samples along the study line in central Finland. The proportion of illitic micas $(10 \AA)$ relative to clay minerals with the $14 \AA$ spacing was estimated from the reflection intensities of the $10 \AA$ and $14 \AA$ lines, and presented in the figure: the intensity of a peak is $<$ smaller than, > higher than, or = equal.

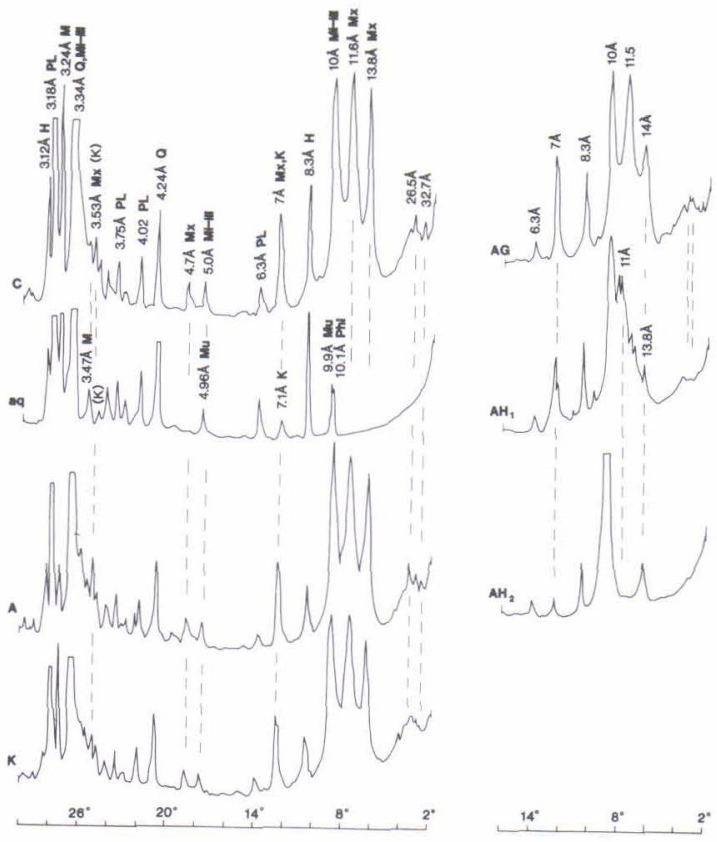

Fig. 6. X-ray diffraction traces of the oriented aggregates of sample No. 8 representing the sample from the non-anomalous zone on the study line in central Finland. Treatments: $\mathrm{C}=$ air dried, $\mathrm{aq}=$ aqua regia leached, $\mathrm{A}=\mathrm{ANC}_{\mathrm{pH} 2.3-2.4}$ extracted, $\mathrm{K}=\mathrm{K}$ saturated, $\mathrm{AG}=\mathrm{ANC}_{\mathrm{pH} 2.3-2.4}$ extracted and solvated with ethylene glycol, $\mathrm{AH}_{1}=\mathrm{ANC}_{\mathrm{pH} 2.3-2.4}$ extracted and heated to $200^{\circ} \mathrm{C}, \mathrm{AH}_{2}=\mathrm{ANC}_{\mathrm{pH} 2.3-2.4}$ extracted and heated to $550^{\circ} \mathrm{C}$. For other abbreviations, see Fig. 3. 


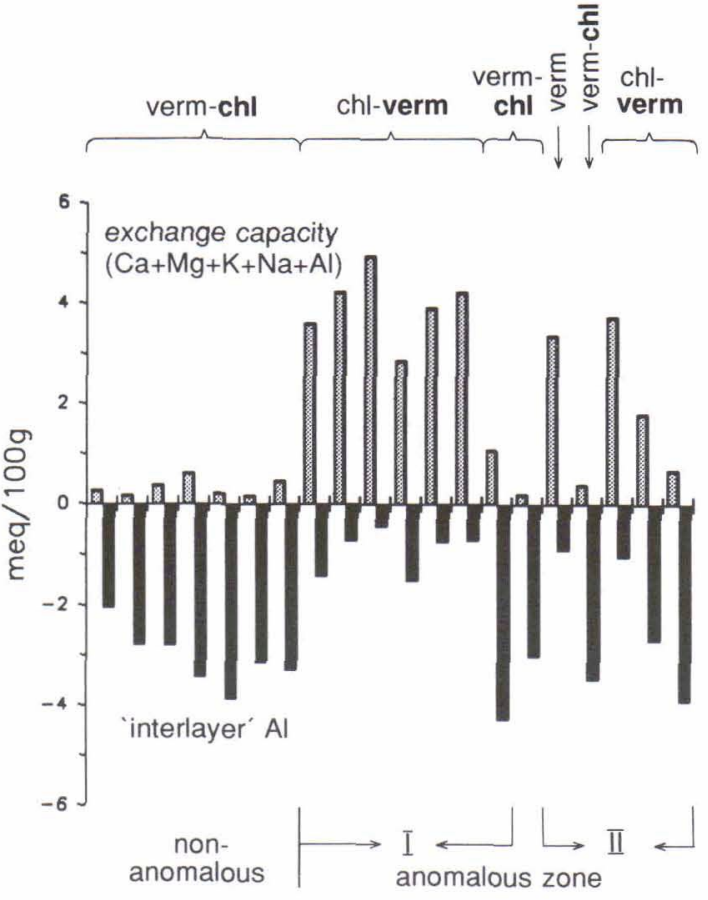

Fig. 7. The exchange capacity calculated as a sum of $\mathrm{Ca}$, $\mathrm{Mg}, \mathrm{K}, \mathrm{Na}$ and $\mathrm{Al}$ extracted with the $\mathrm{NH}_{4} \mathrm{NO}_{3}$ solution (light grey histograms) and $\mathrm{Al}$ concentration in the $\mathrm{ANC}_{\mathrm{pH} 2.3-2.4}$ extraction called 'interlayered' $\mathrm{Al}$ (opposite numbers, black histograms) along the study line in central Finland. In the same figure the predominance (bold letters) of chloritic (chl) or vermiculitic (verm) layers in interstratified clays is based on the results of X-ray diffraction analyses.

(020 spacing) remained after acid digestion also refers to the presence of insoluble dioctahedral mica, probably to sericite (Fig. 3 a) (Thorez 1975, Fanning \& Keramidas 1977).

The weak intensity of the $1.53 \AA$ spacing attributed to trioctahedral, $\mathrm{Mg}$-rich phlogopite was observed in most samples together with the 1.54 $\AA$ spacing of quartz after the aqua regia digestion (Fig. 3). However, the intensity of the 1.53 $\AA$ reflection decreased in most cases after the digestion, suggesting partial dissolution of illitic phlogopite (Fig. 3). Another sign of the residual phlogopite was a weak peak at $10.1 \AA$ or a broad reflection at $10 \AA$, which occurred together with the stronger and sharper reflection at $9.9 \AA$ at- tributed to the dioctahedral muscovite (Figs. 3 and 6).

In summary, it is suggested that the trioctahedral micas of the fine fraction of till mostly dissolve in aqua regia leach, biotite totally and $\mathrm{Mg}$ phlogopite partially. But the dioctahedral micas (muscovite or sericite) did not significantly decompose in the aqua regia digestion of this study.

Clay minerals

The characteristics of the clay minerals in the oriented aggregates of the silt-clay fraction $(<0.04 \mathrm{~mm}$ or $<0.05 \mathrm{~mm})$ did not differ significantly from those of clay mineral types in the aggregates representing the finer fraction $(<0.02$ $\mathrm{mm})$. The coarser fraction $(<0.04 \mathrm{~mm}$ or $<0.05$ $\mathrm{mm})$ including the pure clay fraction $(<0.002$ $\mathrm{mm}$ ) used in the XRD analysis of this study did not only expose mixed-layer mineral types of the silt-sized fraction but also clay minerals of the clay-sized fraction.

The clay mineral group in both the non-anomalous and anomalous zones is composed of mixed-layer clays with variable amounts of chloritic component. The randomly interstratified mineral with the $14 \AA$ spacing was the main clay mineral, and the mixed-layer mineral with the 12 A spacing the accessory in most samples. Neither the pure illite, a nonexpanding, dioctahedral claysize mineral $(<4 \mu \mathrm{m})$ described by Środon and Eberl (1984), nor the swelling illitic types with a smectite component described by Wilson (1987) was observed. It is suggested that illitic clay exists as a mixed layer in micas, producing a broad spacing at 10.0-10.3 $\AA$ as described in the section Micas.

The interstratified mineral with the $14 \AA$ spacing was either a vermiculite-chlorite or a chlorite-vermiculite, depending on the predominance of the chloritic component (Fig. 7). Neither the $14 \AA$ nor the $12 \AA$ clay mineral swelled upon ethylene glycol solvation. In all the samples studied, the $14 \AA$ clays had Al-hydroxides blocking the exchange sites of the vermiculite component (chloritic or Al-hydroxy interlayers), 
a)

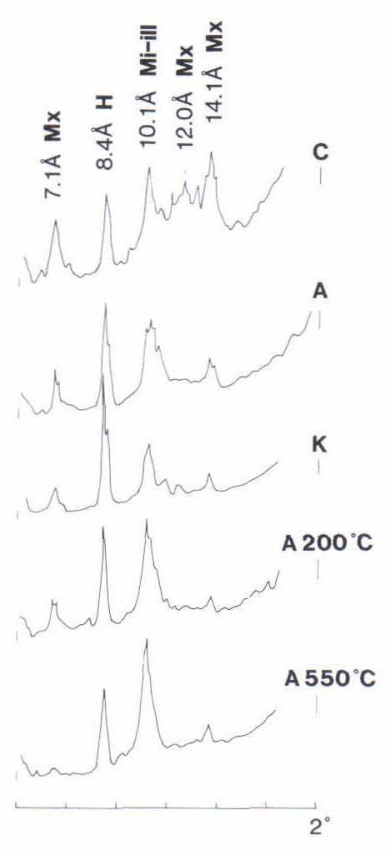

b)

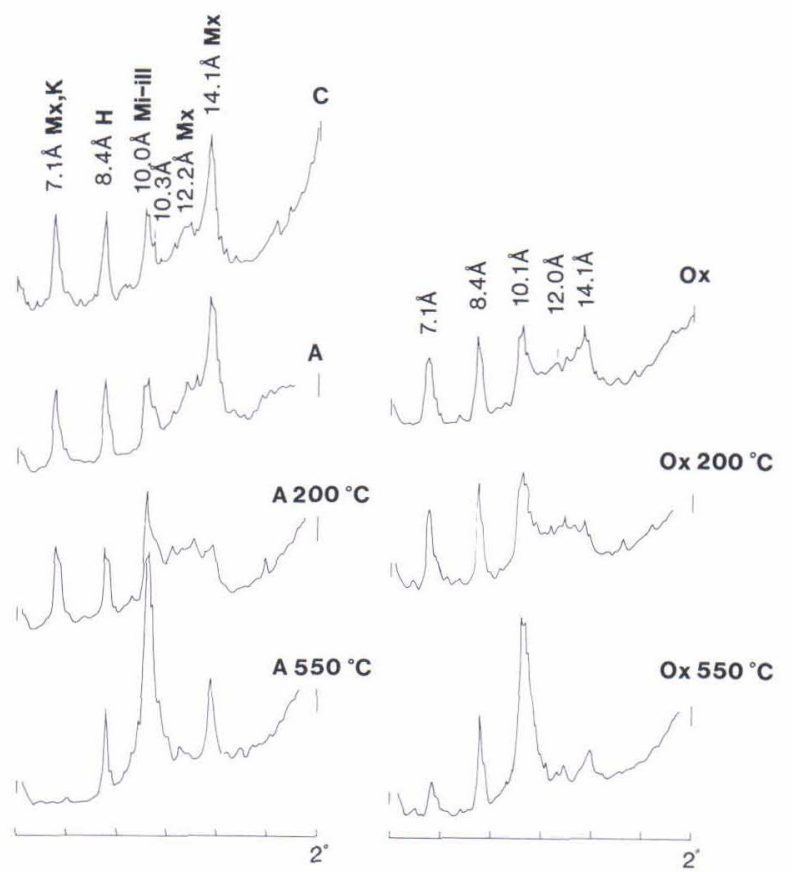

Fig. 8. X-ray diffraction traces of the oriented aggregates of (a) sample No. 13 and (b) sample No. 19 representing the anomalous zone along the study line, in central Finland. Treatments: see Fig. 6 , and $\mathrm{Ox}=$ acid oxalate extracted, $\mathrm{Ox} 200^{\circ} \mathrm{C}=\mathrm{acid}$ oxalate extracted and heated to $200^{\circ} \mathrm{C}$, Ox $550^{\circ} \mathrm{C}=$ acid oxalate extracted and heated to $550^{\circ} \mathrm{C}$. For abbreviations, see also Fig. 3.

which prevented the interlayer space from contracting to exactly $10 \AA$ at $\mathrm{K}$ saturation without heat treatment (Figs. 6 and 8 a). Mica-vermiculite with a broad spacing at $12 \AA$ also had a variable amount of Al-hydroxy units in the interlayer space (Figs. 6 and 8).

The effect of extraction with acidic $\mathrm{NH}_{4} \mathrm{NO}_{3}$ ( $=\mathrm{ANC}_{\mathrm{pH} 2.3-2.4}$ extraction) in getting the vermiculitic layer to collapse towards $10 \AA$ is comparable to that obtained with $\mathrm{K}$ saturation (Figs. 6 and 8). The increase in the extractability of $\mathrm{Al}$ with $\mathrm{ANC}_{\mathrm{pH} 2.3-2.4}$ was consistent with the presence of interlayering in the clay minerals, and the stability of Al-hydroxy interlayers at heating. According to MacEvan and Wilson (1980), when treated with dilute acid, protons attack silicate layers via the interlayer region and exposed edges. The acidic $\mathrm{NH}_{4} \mathrm{NO}_{3}$ solution used in the present study did not destroy the structure of the clay minerals, nor did it liberate octahedral ions, for instance $\mathrm{Al}$, which could then have precipitated as hydroxyl groups in the interlayer space. It is thought that the $\mathrm{ANC}_{\mathrm{pH} 2.3-2.4}$ solution extracts labile Al-hydroxides from the edges and interlayer space, and also from precipitates, but that it is a weaker extractant than the acid oxalate (see Fig. 8 b, and the next paragraph). Therefore, the $\mathrm{Al}$ concentration extracted with $\mathrm{ANC}_{\mathrm{pH} 2.3-2.4}$ is called an 'interlayer' $\mathrm{Al}$ in this context.

Acid $\mathrm{NH}_{4}$-oxalate extraction effectively leaches $\mathrm{Al}$ and $\mathrm{Fe}$ from precipitates (McKeague \& Day 1966), but also Al-hydroxides tightly bound to interlayer spaces of clay minerals as shown in Fig. 8 b. In Fig. 8 b, the $14 \AA$ spacing partially collapsed towards $10 \AA$, even at room temperature, after the oxalate extraction, and 
when heated to $550^{\circ} \mathrm{C}$ after $\mathrm{ANC}_{\mathrm{pH} 2.3-2.4}$ extraction. Furthermore, after the heating, a greater reduction in the intensity of the $14 \AA$ peak of the chloritic component was achieved by extracting the samples with acid oxalate rather than with $\mathrm{ANC}_{\mathrm{pH} 2.3-2.4}$ solution (Fig. 8 b).

The degree of filling of the interlayers of clay minerals determined with the extraction and heating treatments was used to estimate the amount of chloritic component and the stability of the Al-hydroxy interlayers in the mixed-layer minerals. According to Barnhisell (1977), the more tightly the polymers are bound to the interlayers the higher the temperature that is needed to get the $14 \AA$ or $12 \AA$ peak to collapse towards $10 \AA$. As the filling of the interlayer space with hydroxy polymers approaches completeness it becomes increasingly difficult to distinguish the XRD pattern from that of chlorite (Barnhisell 1977, Weaver 1989). Moreover, interlayering with hydroxy polymers impairs the exchange capacity of clay minerals (Jackson 1963, Rich 1968).

The $14 \AA$ peak in the oriented aggregate representing the anomalous zone collapsed to 10 $\AA$ almost completely at room temperature after both $\mathrm{K}$ saturation and $\mathrm{ANC}_{\mathrm{pH} 2.3-2.4}$ extraction. The distinct increase in the intensity of the $10 \AA$ peak after heating at $550^{\circ} \mathrm{C}$ implies the presence of some Al-hydroxy interlayers (Fig. 8 a). Otherwise, a complete shifting and an increase in the intensity of $10 \AA$ in oriented aggregates from the non-anomalous and anomalous II zones were not observed until samples were heated to $550^{\circ} \mathrm{C}$ (Figs. 6 and 8). In both cases the residual spacing of $14 \AA$ observed after heating refers to the presence of a chloritic component or a high degree of filling (strongly bound polymeric Al-hydroxides).

In the anomalous I zone, the mixed-layer minerals of $14 \AA$ have more vermiculitic components with a weaker interlayering character than have those in the non-anomalous zone, where either chloritic component or Al-hydroxy interlayering predominates (Fig. 7). As shown by Fig.
7, the abundance of exchangeable cations is highest and that of acid-soluble Al in the interlayer space lowest in most of the samples from the anomalous I zone, thus proving the presence of exchangeable clay minerals. The 'true' chloritic component is present in most of the samples from the non-anomalous zone, resulting in lowered exchangeability of the clay minerals. In some samples from the anomalous II zone the $14 \AA$ mixed-layer mineral has vermiculitic hydroxy-Al interlayers, and in others weak interlayering, implying higher exchangeability (Figs. 7 and 8 b).

The abundance of the $12 \AA$ mixed-layer clay varied from sample to sample. On average, the abundance was greater in the anomalous II zone than in the other two areas. The $12 \AA$ clay was observed in marked concentrations in samples No. 8, 9, 13, 18, 20 and 21. Kaolinite was occasionally observed in minor amounts in both zones.

Hot aqua regia leach dissolved the clay minerals with the $12 \AA$ and $14 \AA$ spacings completely (Figs. 3 and 6). However, as seen in Figs. 3 b and 6, kaolinite did not decompose in every case.

\section{Clay minerals in weathered bedrock}

The clay minerals in the composite sample of weathered bedrock from the anomalous zone were mostly illitic mica (10 $⿱$ ), but minor amounts of mixed-layer minerals with a broad spacing between $13 \AA$ and $14 \AA$ and a flat reflection of $12 \AA$ were also present. Both mixed-layer minerals showed very weak interlayering and swelled upon ethylene glycol solvation. Broad spacings were displayed between $14.3 \AA$ and 18.0 $\AA$ (Fig. 9 a), implying the presence of the expandable smectite component. Therefore, the clay mineral with the $13-14 \AA$ spacing in weathered bedrock is probably a randomly interstratified smectite-vermiculite with weak interlayering character (no chlorite). Furthermore, the weak (almost flat) reflection at $12 \AA$ may refer to a 
a)
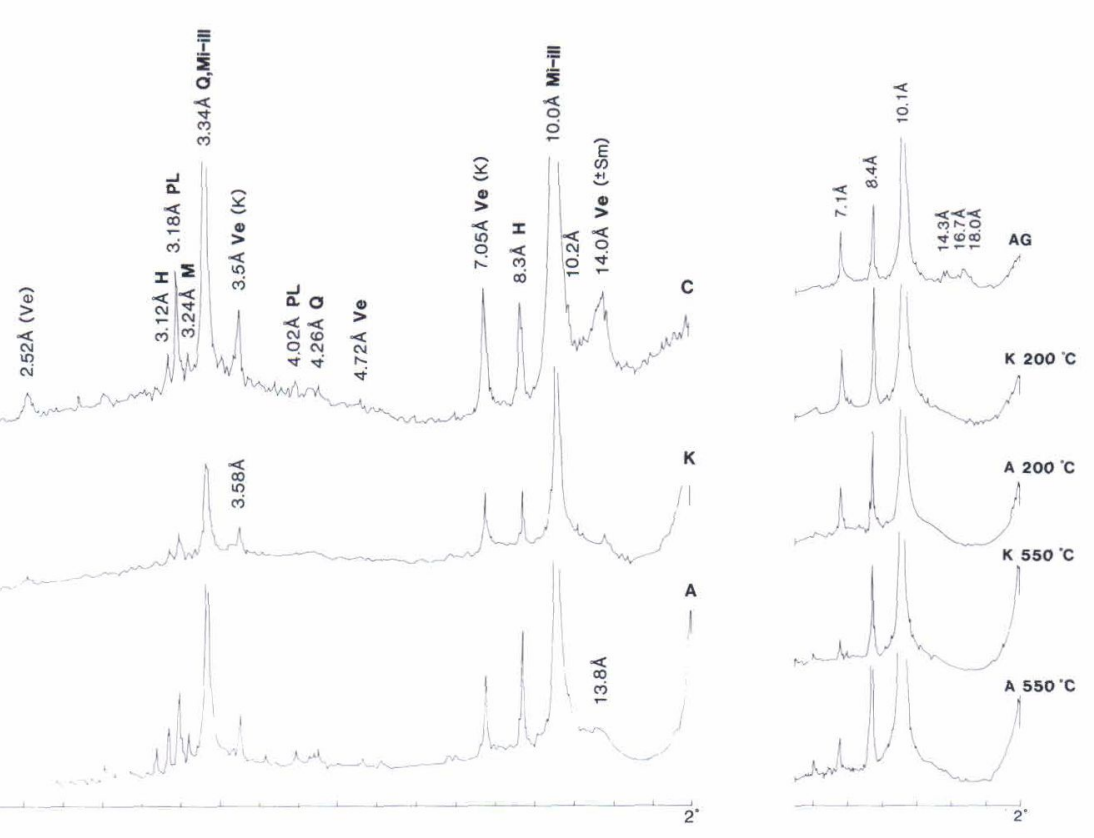

b)
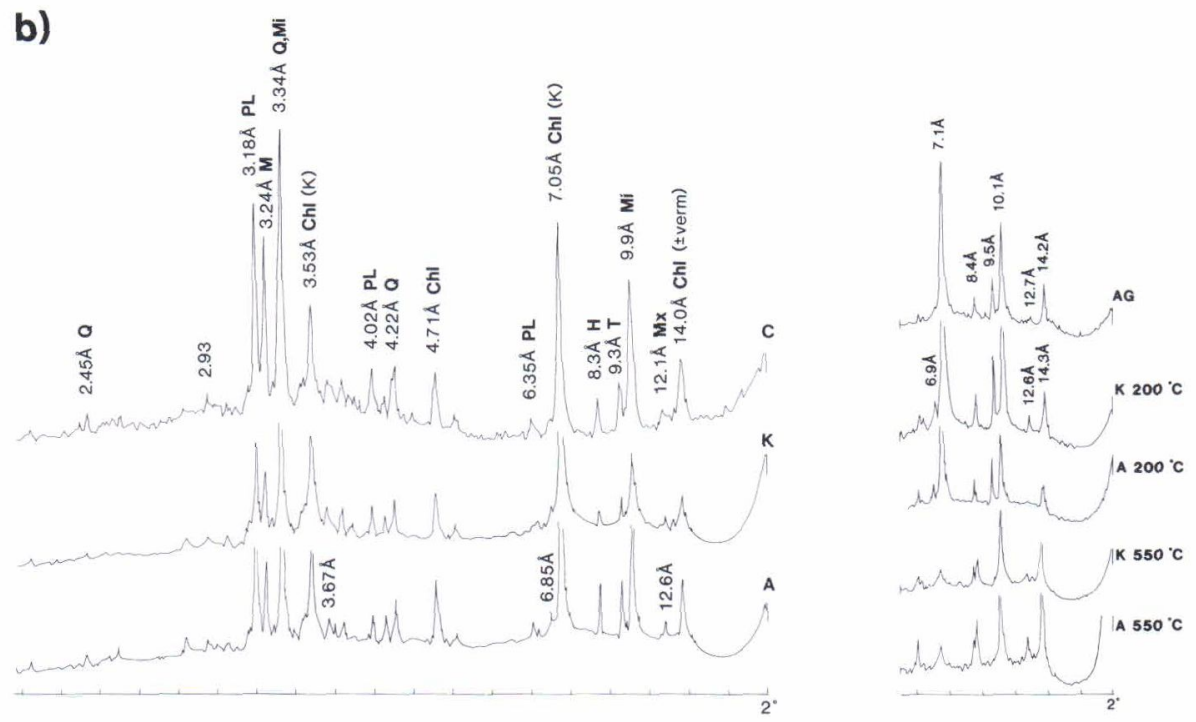

Fig. 9. X-ray diffraction traces of the oriented aggregates of the weathered bedrock from (a) anomalous and (b) non-anomalous zones in central Finland. For abbreviations, see Figs. 3 and 6.

three-component, mixed-layer mica-smectite-vermiculite or to an isolated interstratification of mica-smectite mineral (Sawhney 1977). The high abundance of illitic mica and, overall, the small size of the composite sample for the grain-size and mineralogical separation impeded detailed study of the characteristics of mixed-layer minerals in this case. 
Table 4. The leachability of $\mathrm{Fe}, \mathrm{Al}$ and trace elements ( $\mathrm{Mn}, \mathrm{Co}, \mathrm{Cu}, \mathrm{Ni}, \mathrm{Zn}$ ) in the acid oxalate solution (subindex ox) and aqua regia leach (subindex aq) on the study line, in Central Finland. Samples No. $1-8$ represent the non-anomalous zone and samples No. 9-21 the anomalous zone (shaded numbers).

\begin{tabular}{|c|c|c|c|c|c|c|c|c|c|c|c|c|c|c|}
\hline No. & $\begin{array}{l}\mathrm{Fe}_{\mathrm{ox}} \\
\mathrm{ppm}\end{array}$ & $\begin{array}{c}\mathrm{Fe}_{\mathrm{aq}} \\
\% 0\end{array}$ & $\begin{array}{l}\mathrm{Al}_{\mathrm{ox}} \\
\mathrm{ppm}\end{array}$ & $\begin{array}{c}\mathrm{Al}_{\mathrm{aq}} \\
\% 0\end{array}$ & $\begin{array}{l}\mathrm{Mn}_{\mathrm{ox}} \\
\mathrm{ppm}\end{array}$ & $\begin{array}{c}\mathrm{Mn}_{\mathrm{aq}} \\
\mathrm{ppm}\end{array}$ & $\begin{array}{l}\mathrm{Co}_{\mathrm{ox}} \\
\mathrm{ppm}\end{array}$ & $\begin{array}{l}\mathrm{Co}_{\mathrm{aq}} \\
\mathrm{ppm}\end{array}$ & $\begin{array}{l}\mathrm{Cu}_{\mathrm{ox}} \\
\mathrm{ppm}\end{array}$ & $\begin{array}{l}\mathrm{Cu}_{\mathrm{aq}} \\
\mathrm{ppm}\end{array}$ & $\begin{array}{l}\mathrm{Ni}_{\mathrm{ox}} \\
\mathrm{ppm}\end{array}$ & $\begin{array}{l}\mathrm{Ni}_{\mathrm{aq}} \\
\mathrm{ppm}\end{array}$ & $\begin{array}{l}\mathrm{Zn}_{\mathrm{ox}} \\
\mathrm{ppm}\end{array}$ & $\begin{array}{l}\mathrm{Zn}_{\mathrm{aq}} \\
\mathrm{ppm}\end{array}$ \\
\hline 1 & 631 & 1.07 & 499 & 0.46 & 6 & 110 & 0.6 & 4 & 1.5 & 7 & 2.4 & 7 & 2.0 & 13 \\
\hline 2 & 412 & 1.25 & 1346 & 0.66 & 8 & 126 & 1.0 & 4 & 1.5 & 9 & 0 & 7 & 2.3 & 20 \\
\hline 3 & 698 & 1.27 & 1240 & 0.65 & 16 & 147 & 0 & 5 & 0.9 & 8 & 1.2 & 8 & 1.1 & 16 \\
\hline 4 & 3340 & 1.71 & 4058 & 1.21 & 107 & 257 & 1.5 & 7 & 4.0 & 16 & 1.1 & 12 & 1.4 & 32 \\
\hline 5 & 563 & 1.28 & 2262 & 0.72 & 15 & 131 & 0.2 & 4 & 1.5 & 8 & 1.0 & 8 & 2.4 & 13 \\
\hline 7 & 1200 & 1.48 & 2153 & 0.78 & 13 & 150 & 1.0 & 5 & 1.2 & 10 & 0.6 & 10 & 2.8 & 18 \\
\hline 8 & 1290 & 1.66 & 5124 & 1.63 & 1 & 160 & 0.9 & 8 & 2.7 & 28 & 1.0 & 18 & 4.1 & 35 \\
\hline 9 & 7580 & 3.80 & 1710 & 2.39 & 85 & 405 & 3.0 & 17 & 5.4 & 43 & 2.7 & 34 & 5.1 & 76 \\
\hline 10 & 7650 & 3.00 & 1107 & 1.89 & 174 & 459 & 4.4 & 13 & 4.7 & 28 & 2.0 & 24 & 3.2 & 53 \\
\hline 11 & 5406 & 3.14 & 866 & 1.68 & 214 & 518 & 4.6 & 14 & 7.2 & 30 & 4.1 & 27 & 10.5 & 58 \\
\hline 12 & 5527 & 2.85 & 2197 & 1.54 & 152 & 421 & 4.3 & 16 & 5.7 & 27 & 2.3 & 28 & 6.9 & 57 \\
\hline 13 & 4512 & 2.55 & 911 & 1.80 & 79 & 284 & 3.4 & 10 & 3.8 & 25 & 3.0 & 21 & 5.9 & 45 \\
\hline 14 & 5705 & 3.05 & 1432 & 1.90 & 140 & 404 & 3.6 & 13 & 5.1 & 30 & 1.3 & 24 & 4.9 & 55 \\
\hline 15 & 5242 & 2.12 & 3630 & 1.48 & 62 & 243 & 2.4 & 10 & 3.8 & 19 & 1.8 & 17 & 4.4 & 35 \\
\hline 16 & 812 & 1.11 & 1996 & 0.53 & 10 & 102 & 1.0 & 4 & 1.1 & 7 & 0.3 & 7 & 4.5 & 9 \\
\hline 17 & 5096 & 2.33 & 925 & 1.28 & 64 & 230 & 2.1 & 9 & 3.1 & 18 & 1.9 & 18 & 5.5 & 33 \\
\hline 18 & 1055 & 2.98 & 2103 & 1.98 & 29 & 259 & 2.5 & 17 & 2.4 & 46 & 0.2 & 47 & 4.6 & 65 \\
\hline 19 & 6021 & 3.11 & 2193 & 2.01 & 130 & 409 & 3.2 & 14 & 4.3 & 22 & 2.7 & 33 & 6.1 & 71 \\
\hline 20 & 4824 & 2.49 & 2092 & 1.89 & 51 & 236 & 3.4 & 12 & 2.0 & 26 & 1.7 & 27 & 3.6 & 42 \\
\hline 21 & 1962 & 2.33 & 3681 & 1.75 & 59 & 273 & 1.9 & 12 & 3.6 & 29 & 1.0 & 29 & 1.6 & 46 \\
\hline
\end{tabular}

According to the peak intensities, the proportion of illitic mica relative to the clay minerals with $14 \AA$ spacing was considerably lower in the non-anomalous zone than in the anomalous zone (Fig. 9). The reflection at $14 \AA$ in the composite sample from the non-anomalous zone showed hardly any change due to $\mathrm{K}$ saturation and $\mathrm{ANC}_{\mathrm{pH} 2.3-2.4}$ extraction, implying the presence of pure chlorite with non-detectable vermiculitic layers (Fig. 9 b). The $12 \AA$ mixed-layer clay in the non-anomalous zone is attributed to micachlorite or hydrobiotite on the basis of its stability at $550^{\circ} \mathrm{C}$. According to observations of Reynolds (1980), the diffraction patterns of micachlorite and hydrobiotite are too alike to be reliably distinguished.

The predominance of less weathered biotite and chlorite in the composite sample from the non-anomalous zone might be due to material from the unweathered bedrock pulverized fine during drilling at some sampling sites. Otherwise, the presence of kaolinite (strong peak at $7 \AA$ ) in the oriented aggregate refers to the presence of weathered bedrock material (in cracks) at least at some sampling sites. Talc ( $9.3 \AA$ ), too, was present in minor amounts in the weathered bedrock of the non-anomalous zone (Fig. 9 b).

\section{Relationship between mineralogical and physico-chemical properties of the fine fraction of till}

The iron, aluminium and trace element $(\mathrm{Co}$, $\mathrm{Cu}, \mathrm{Ni}, \mathrm{Zn}$ ) contents of the fine fraction of till determined with aqua regia leach were distinctly higher in the anomalous than in the non-anomalous zone (Table 4). Even though the concentrations of $\mathrm{Co}, \mathrm{Cu}, \mathrm{Ni}, \mathrm{Zn}$ extracted from inorganic precipitates with acid oxalate were very low, being near the detection limit of the method, the anomalous zone of the study line was still detectable. The only exception among the elements extracted with acid oxalate was aluminium. Its concentration varied from sample to sample in the 
Table 5 a. Correlation coefficients between the concentrations of elements leached with hot aqua regia, clay content (CC), specific surface area (SSA), unit weight (UW) and mineralogy. $\mathrm{CHL}=$ chlorite and other $14 \AA$ clay minerals, $\mathrm{MI}=$ micas, $\mathrm{H}=$ hornblende, $\mathrm{Q}=\mathrm{quartz}, \mathrm{PL}=$ plagioclase, $\mathrm{KF}=\mathrm{K}$-feldspar .

\begin{tabular}{|c|c|c|c|c|c|c|c|c|c|c|c|c|c|}
\hline & Co & $\mathrm{Cu}$ & $\mathrm{Mn}$ & $\mathrm{Ni}$ & $\mathrm{Pb}$ & $\mathrm{Zn}$ & $\mathrm{Ba}$ & $\mathrm{Fe}$ & $\mathrm{Al}$ & $\mathrm{Mg}$ & K & $\mathrm{Ca}$ & $\mathrm{Na}$ \\
\hline $\mathrm{CU}$ & $.8868 * *$ & & & & & & & & & & & & \\
\hline $\mathrm{Mn}$ & $.8866^{* *}$ & $.7839 * *$ & & & & & & & & & & & \\
\hline $\mathrm{Ni}$ & $.9560 * *$ & $.8807 * *$ & $.8167 * *$ & & & & & & & & & & \\
\hline $\mathrm{Pb}$ & $.9137 * *$ & $.8651 * *$ & $.8562 * *$ & $.9014 * *$ & & & & & & & & & \\
\hline $\mathrm{Zn}$ & $.9701^{* *}$ & $.8926^{* *}$ & $.8962 * *$ & $.9419 * *$ & $.9146 * *$ & & & & & & & & \\
\hline $\mathrm{Ba}$ & $.9635^{* *}$ & $.9258^{* *}$ & $.8809^{* *}$ & $.9079 * *$ & $.8928^{* *}$ & $.9588^{* *}$ & & & & & & & \\
\hline $\mathrm{Fe}$ & $.9380 * *$ & $.8490 * *$ & $.9304 * *$ & $.8891^{* *}$ & $.8812^{* *}$ & $.9492^{* *}$ & $.9421 * *$ & & & & & & \\
\hline $\mathrm{Al}$ & $.8854 * *$ & $.8697^{* *}$ & $.7868 * *$ & $.9121^{* *}$ & $.9006 * *$ & $.9176^{* *}$ & $.8903^{* *}$ & $.9097 * *$ & & & & & \\
\hline $\mathrm{Mg}$ & $.9652 * *$ & $.9089 * *$ & $.8872 * *$ & $.9359 * *$ & $.9131^{* *}$ & $.9850 * *$ & $.9717 * *$ & $.9590^{* *}$ & $.9342 * *$ & & & & \\
\hline $\mathrm{K}$ & $.8918^{* *}$ & $.9669^{* *}$ & $.8000^{* *}$ & $.8567 * *$ & $.8661^{* *}$ & $.9090 * *$ & $.9263^{* *}$ & $.8477^{* *}$ & $.8492 * *$ & $.9263^{* *}$ & & & \\
\hline $\mathrm{Ca}$ & .3413 & .2038 & $.6002 *$ & .2395 & .3022 & .3989 & .4005 & $.5335^{*}$ & .2882 & .4032 & .2640 & & \\
\hline $\mathrm{Na}$ & $.6715^{* *}$ & $.5740^{*}$ & $.8627^{* *}$ & $.5620^{*}$ & $.5900^{*}$ & $.6721^{* *}$ & $.6936^{* *}$ & $.8072^{* *}$ & $.5756^{*}$ & $.6704^{* *}$ & $.5867 *$ & $.7126^{* *}$ & \\
\hline $\mathrm{CC}$ & $.6046^{*}$ & .4460 & $.6963^{* *}$ & $.5401 *$ & $.5535^{*}$ & $.6146^{*}$ & $.5980^{*}$ & $.7444 * *$ & $.6129 *$ & $.6172^{*}$ & .4552 & $.6084^{*}$ & $.6772 * *$ \\
\hline SSA & $.7226^{* *}$ & $.7411^{* *}$ & $.8276 * 0$ & $.7050^{* *}$ & $.6877 * *$ & $.7260 * *$ & $.7756^{* *}$ & $.8504 * *$ & $.7559 * *$ & $.7433^{* *}$ & $.6836^{* *}$ & $.5540^{*}$ & $.8558^{* *}$ \\
\hline UW & $.9261 * *$ & $.7977 * *$ & $.8606^{* *}$ & $.8719 * *$ & $.9053^{* *}$ & $.9223 * *$ & $.8977^{* *}$ & .8937 * & .8692 ** & $.9126^{* *}$ & .8448 ** & .3279 & $.6213^{*}$ \\
\hline $\mathrm{CHL}$ & $.5560^{*}$ & .4781 & $.7268^{* *}$ & .4998 & $.5591^{*}$ & $.5850^{*}$ & $.5524^{*}$ & $.6765^{* *}$ & $.5224^{*}$ & $.5869 *$ & .4941 & .3985 & $.6870^{* *}$ \\
\hline MI & $.5166^{*}$ & $.5460^{*}$ & .4026 & .4552 & $.5272^{*}$ & $.5536^{*}$ & .4695 & .4276 & .4594 & $.5486^{*}$ & $.6678^{* *}$ & -.0371 & .1077 \\
\hline $\mathrm{H}$ & .1326 & .1890 & -.0032 & .1741 & .2817 & .0944 & .0609 & .0080 & .0550 & .0756 & .1274 & -.2127 & -.1757 \\
\hline Q & -.3082 & -.4401 & -.3380 & -.3439 & -.3115 & -.3998 & -.3684 & -.3117 & -.4245 & -.4383 & -.5130 & -.0555 & -.0994 \\
\hline PL & -.4228 & -.3623 & -.2867 & -.3488 & -.2673 & -.3586 & -.4826 & -.3860 & -.3457 & -.3599 & -.2761 & -.2574 & -.2660 \\
\hline $\mathrm{KF}$ & -.1167 & -.0566 & .0377 & -.1334 & -.1578 & -.0905 & -.0193 & -.0260 & -.0490 & -.1235 & -.1379 & .3602 & .1662 \\
\hline
\end{tabular}

Table 5 b. Correlation coefficients between clay content, specific surface area, unit weight and mineralogy. See explanations in Fig. 5 a.

\begin{tabular}{|c|c|c|c|c|c|c|c|c|}
\hline & $\mathrm{CC}$ & SSA & UW & $\mathrm{CHL}$ & MI & $\mathrm{H}$ & Q & PL \\
\hline SSA & $.7629 * *$ & & & & & & & \\
\hline UW & $.6669 * *$ & $.6829 * *$ & & & & & & \\
\hline CHL & $.6808^{* *}$ & $.7234 * *$ & $.6526^{* *}$ & & & & & \\
\hline MI & .1535 & .1489 & $.5598^{*}$ & .2963 & & & & \\
\hline $\mathrm{H}$ & -.2426 & -.2371 & -.0379 & -.3023 & .2229 & & & \\
\hline Q & -.2336 & -.2594 & -.3705 & -.2159 & -.4918 & .2984 & & \\
\hline PL & -.1406 & -.3496 & -.2677 & .0824 & .0709 & -.1079 & -.1756 & \\
\hline KF & .2635 & .2938 & -.1623 & -.1832 & -.4692 & -.2752 & -.0756 & -.2698 \\
\hline
\end{tabular}


same way as did $\mathrm{Al}$ extracted with $\mathrm{ANC}_{\mathrm{pH} 2.3-2.4}$ along the study line (Table 4, Fig. 7). The concentration of $\mathrm{Al}$ was lowest in samples with predominant exchangeable vermiculitic clay minerals (Fig. 7).

The relationship between the concentrations of elements leached with hot aqua regia and the physical and mineralogical properties of the fine fraction of till was studied with Varimax-rotated factor analysis. Factor 1 (total variation= $62.2 \%$ ), called a mica factor in this study, contained the main elements ( $\mathrm{Fe}, \mathrm{Al}, \mathrm{Mg}, \mathrm{K}$ ), all the trace elements ( $\mathrm{Ba}, \mathrm{Co}, \mathrm{Cu}, \mathrm{Mn}, \mathrm{Ni}, \mathrm{Pb}, \mathrm{Zn})$ and, of the physical properties, specific surface area, unit weight and mica group. As seen in Table 5 a, the correlation coefficients between the main elements and the trace elements are significant. Moreover, in the mica factor the correlation between unit weight and chemical content is even better than that between unit weight and specific surface area.

Factor 2 (total variation $=12.2 \%$ ), called in this context the clay and precipitate factor, contains $\mathrm{Na}, \mathrm{Ca}, \mathrm{Fe}, \mathrm{Mn}$, clay content, specific surface area and the clay minerals with the $14 \AA$ spacing. The values of the correlation coefficients between each variable are lower than those of the coefficients between the variables in the mica factor (Table 5). As expected, the clay mineral group of $14 \AA$ correlates slightly better with the specific surface area values than with the others (Table 4). Factors 3 and 4, which include the main silicates minerals, were less significant (cf. Mäkinen 1992).

The matrix configuration (Table 5) of the selected variables is visualized with multidimensional scaling in Fig. 10. The unit weight correlates best with the chemical variables, as also reported by Mäkinen (1992). According to factor analysis, most of the trace elements and values of unit weight are related to the occurrence of micas.

The significant correlation between the main elements $(\mathrm{Fe}, \mathrm{Al}, \mathrm{Mg}, \mathrm{K}$ ) characteristic of micas and clay minerals and the trace elements $(\mathrm{Co}, \mathrm{Cu}$,

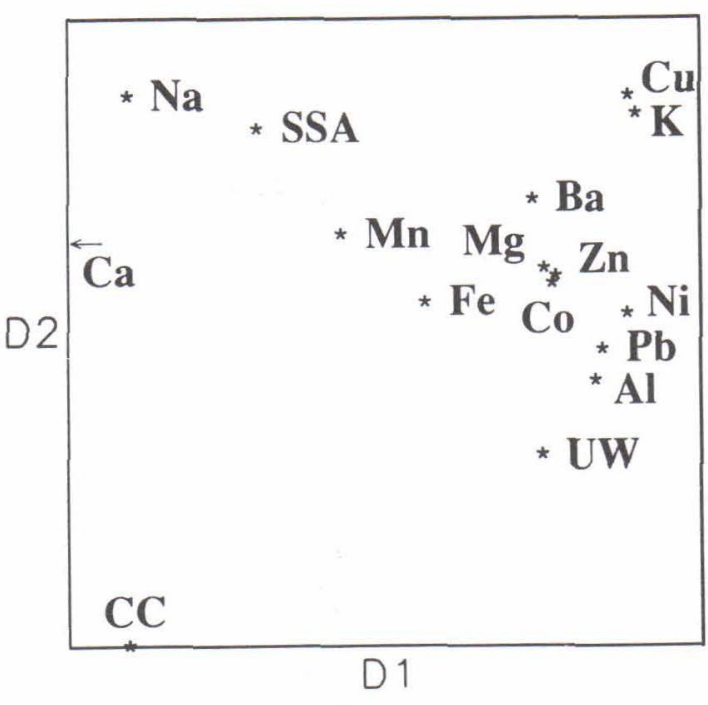

Fig. 10. Multidimensional scaling of the rank correlation matrix. For abbreviations, see Table 5 .

$\mathrm{Mn}, \mathrm{Ni}, \mathrm{Pb}, \mathrm{Zn}$ ) implies that the trace elements in both the anomalous and non-anomalous zones are mostly incorporated in the structures of micas and clay minerals. Moreover, the concentrations of $\mathrm{Co}, \mathrm{Cu}, \mathrm{Ni}$ and $\mathrm{Zn}$ in iron precipitates were too low to refer to a hydromorphic origin of the anomalous zone in till.

\section{Origin of clay minerals in the fine fraction of till}

The predominance of illitic mica and chloritic component in the clay mineralogy the only similarity between the weathered bedrock in and the till samples from the non-anomalous zone. Otherwise, the similarities between the weathered bedrock and till were minor in both study area types.

The mixed-layer minerals in the till samples have a non-expanding vermiculite component with variable amounts of the mica or chlorite component in both the non-anomalous and the anomalous (I, II) zones (Fig. 7). The absence of the swelling smectite component from the till samples indicates that the source of their ver- 
miculitic clay types is not the underlying weathered bedrock, especially in the anomalous area. Furthermore, the Al-hydroxy interlayering was lacking or only weakly developed in the samples of weathered bedrock, in striking contrast to its predominance in till samples from the nonanomalous zone, and its variable occurrence in the anomalous I and II zones. However, it is unlikely that the original smectite component had been transformed into a vermiculitic clay type with Al-hydroxy interlayers during postglacial weathering.

Generally, the chemical weathering of clay minerals shows the following sequence (Weaver 1989, Wilson 1970, see also Melkerud 1984):

mica-illite $\rightarrow$ illite-vermiculite $\rightarrow$ vermiculite $\rightarrow$ vermiculite-smectite $\rightarrow$ smectite

chlorite $\rightarrow$ (chlorite-swelling chlorite) $\rightarrow$ chlorite-vermiculite $\rightarrow$ smectite

or chlorite and chlorite-vermiculite simply decompose into an amorphous phase rather than being transformed into another clay mineral, especially under acid conditions (McKeague \& Brydon 1970, Bain 1977, Kodama 1979, Churchman 1980).

The presence of the smectite component in the mixed-layer mineral indicates a higher weathering degree in the weathered bedrock than does the vermiculite in the overlying till. The combination of chlorite, vermiculite and mica-vermiculite of $12 \AA$ reflects moderate weathering in a cold and temperate climate and, generally, represents a common clay group in glacial deposits (Kodama \& Brydon 1968, Weaver 1989). According to studies of Weaver (1958 and 1989), vermiculite and mixed-layer mica-vermiculite are rare in marine sediments, but they do occur in continental sediments. Sippola (1974) has observed a swelling interstratified clay-type smectite-vermiculite in the argillaceous soils of southern Finland.

Acidic percolating waters in soils mostly activate $\mathrm{Al}$ hydroxides to precipitate in the interlayer space of vermiculite, not only in vermiculites of the clay fraction but also in those of the silt fraction (Jackson 1963, Carstea 1968, Carstea et al. 1970). Carstea et al. (1970) have shown that $\mathrm{Al}$ interlayers can be formed in vermiculites, even in a short period of time. According to studies of Jackson (1963) and Rich (1968), interlayering appears to form at $\mathrm{pH} \mathrm{5.0,} \mathrm{at} \mathrm{sites} \mathrm{where} \mathrm{there}$ is low organic matter and frequent wetting and drying. This process is generally observed in the $\mathrm{B}$ and BC layers of podzols in glaciated regions (Kapoor 1972, Melkerud 1984, Räisänen \& Jylänki 1990).

In the present study, however, the interlayered mixed-layer minerals were identified from the parent till at a depth of $1-3 \mathrm{~m}$. The $\mathrm{pH}$ of the till samples varied from 4.5 to 5.3 (one exception: sample No. 15 with pH 4.3). This implies slightly acidic conditions at the sampling depth, which was less than $50 \mathrm{~cm}$ as measured from the uncovered surface on the bottom of the road cutting. The $\mathrm{pH}$ of till layers at a depth greater than $1.5 \mathrm{~m}$ from the surface soil is generally higher (above 6) than the $\mathrm{pH}$ values of the till measured in this study (Nuotio et al. 1990). Because of the variable occurrence of Al-hydroxy interlayers in clay minerals along the study line, the interlayering may be formed more likely in postglacial than in interstadial or interglacial time. Furthermore, the lability of the interlayering at some sampling sites seems to be promoted by contemporary acidic leaching caused by water percolating through the thin till layer. However, the definite evidence of postglacial weathering needs more attention in vertical profiles from the weathered bedrock up to topsoil.

The till with vermiculitic clay minerals, which is the predominant type in the anomalous zone, contains old sediments weathered in interstadial or interglacial time. The till in the non-anomalous zone is richer in sandy fraction than the till in the anomalous zone but is less mixed with old sediments owing to the different dynamics of transport and the accumulation of overdrift. Thus, the differences observed in the trace ele- 
ment contents of mica gneiss between the nonanomalous and anomalous zones are masked by glacial process (cf. Mäkinen 1991, 1992).

\section{Conclusions}

This study of the chemical and physical characteristics of the fine fraction of till in the area of the Raahe-Ladoga metallogenic belt in central Finland has led to the following conclusions. Concentrations of elements leached with hot aqua regia, and the clay content of the fine fraction of till were found to change abruptly in the area from southwest (non-anomalous zone) to northeast (anomalous zone). The significant correlation between the main elements ( $\mathrm{Fe}, \mathrm{Al}$, $\mathrm{Mg}, \mathrm{K}$ ) characteristic of the micas (biotite) and clay minerals and the trace elements $(\mathrm{Co}, \mathrm{Cu}$, $\mathrm{Mn}, \mathrm{Ni}, \mathrm{Pb}, \mathrm{Zn}$ ) dissolved in aqua regia implies that the trace elements in both zones are mostly bound to structures of the micas and clay minerals. Moreover, the concentrations of $\mathrm{Co}, \mathrm{Cu}$, $\mathrm{Ni}$ and $\mathrm{Zn}$ in the iron precipitates extracted with acid oxalate were too low to be used as evidence of the hydromorphic origin of the anomalous zone in the fine fraction of till.

The main factor affecting the increased element concentrations in the anomalous zone appears to be the variation in mica and clay mineral types. The dioctahedral illitic micas, which were insoluble in hot aqua regia, occur as the predominant mica group in the non-anomalous zone, whereas the trioctahedral (Fe-rich) micas, which did dissolve in the leach, dominate in the anomalous zone. Furthermore, the mixed-layer clay minerals differed in characteristics from the others, having more vermiculitic components with higher exchangeability in the anomalous zone than in the non-anomalous zone. In the non-anomalous zone the mixed-layer minerals had either a predominant chloritic component or Al-hydroxy interlayering.
However, the semiquantitative abundances and types of the main silicates (feldspars, quartz) did not vary much in the fine fraction in relation to the physical properties of the till types. The aqua regia leach did not dissolve feldspars, amphiboles and quartz as well as it did micas and clay minerals. It is suggested that the elements leached in minor amounts from feldspars and amphiboles are bound to their broken surfaces.

The absence of the swelling smectite component from the surface layers of the till indicates that the source of their vermiculitic clay types was not the underlying weathered bedrock, especially in the anomalous area of this study. The till was intermixed with old sediments weathered during interstadial or interglacial time to a greater extent than was the till poor in clay in the nonanomalous zone. The abrupt change in the mineralogical and physical properties of the till in the study area is attributed to the different transport and accumulation dynamics of overburden during deglaciation.

The variable occurrence of Al-hydroxy interlayers in the surface layers of the till indicates that the interlayering was more probably formed during postglacial than interstadial or interglacial time. However, in further studies samples should be taken from deep enough or from the whole profile, starting with the weathered bedrock and continuing up to the topsoil to avoid the secondary effects of contemporary acidic leaching.

Acknowledgements. The authors firstly acknowledge Mr. Jouko Jylänki, who made the weak extractions and prepared XRD-slides, and furthermore, assisted with the XRD-identification of minerals. We sincerely thank Dr. Pekka Kallio, who made the semiquantitative mineral analysis of the randomly oriented aggregates, and also Lic. Ph. Petri Lintinen for the measurements of the specific surface area. The authors are grateful to prof. Reijo Salminen, prof. Heikki Papunen, and particularly the colleagues at the Geochemistry Department of the GFS for their interest and constructive criticism throughout the various stages of the study. 


\section{References}

Bain, D.C., 1977. Weathering of ferruginous chlorite in podzol from Argyllshire, Scotland. Geoderma 17, 193-208.

Barnhisell, R.I., 1977. Chlorites and hydroxy interlayered vermiculite and smectite. In: J.B. Dixon and S.B. Weed, Minerals in Soil Environments, Soil Science Society of America, Madison, Wisconsin, 331-356.

Brindley, G.W., 1961. Kaolin, serpentine, and kindred minerals. In: G. Brown (ed), The X-ray identification and crystal structures of clay minerals. Mineralogical Society, London, 51-131.

Brindley, G.W. \& Brown, G. 1980. Crystal structures of clay minerals and their X-ray identification. Mineralogical Society Monograph No. 5, London, 495 p.

Carstea, D.D., 1968. Formation of hydroxy-Al and -Fe interlayers in montmorillonite and vermiculite: influence of particle size and temperature. Clays and Clay Minerals 16, 231-238.

Carstea, D.D., Harward, H.E., \& Knox, E.G., 1970. Comparison of iron and aluminum hydroxy interlayers in montmorillonite and vermiculite: I. Formation. Soil Science Society of America Proceedings 34, 517-521.

Churchman, G.J., 1980. Clay minerals formed from micas and chlorites in some New Zealand soils. Clay Minerals $15,59-76$.

Dixon, J.B. \& Weed, S.B., 1977. Minerals in Soil Environments. Soil Science Society of America, Madison, Wisconsin, $947 \mathrm{p}$.

Douglas, L.A., 1977. Vermiculites. In: J.B. Dixon and S.B. Weed, Minerals in Soil Environments, Soil Science Society of America, Madison, Wisconsin, 259-292.

Dreimanis, A. \& Vagners, U.J., 1971 a. Bimodal distribution of rock and mineral fragments in basal tills. In: R. P. Goldthwait (Ed). Till, a Symposium, Ohio State University Press, 237-250.

Dreimanis, A. \& Vagners, U.J., 1971 b. The effect of lithology upon texture of till. In: E. Yatse \& A. Falconer (Eds). Research methods in Pleistocene geomorphology, 2nd symposium on geomorphology. Geo Abstract Ltd. England, 66-82.

Ekdahl, E., 1982. Glacial history and geochemistry of till/ bedrock interface in prospecting in Pielavesi area Central Finland. In Prospecting in Areas of Glaciated Terrain 1982. IMM, London, 213-227.

Eriksson, K., 1973. The distribution of some metals in different till fractions. Geological Institute, University of Uppsala Bulletin 5, 157-164.

Fanning, D.S. \& Keramidas, V.Z., 1977. Micas. In: J.B. Dixon and S.B. Weed, Minerals in Soil Environments, Soil Science Society of America, Madison, Wisconsin, $195-258$.

Farrar, D.M. \& Coleman, J.D., 1967. The correlation of surface area with other properties of nineteenth British clay soils. Journal of Soil Science 18, 118-124.

Fletcher, W.K., 1981. Analytical methods in Geochemical Prospecting. In: G.J.S. Govett (Ed). Handbook of Exploration Geochemistry. Elsevier, New York, 255 p.

Foster, J.R., 1971. The reduction of matrix effects in atomic absorption analysis and the efficiency of selected extractions on rock-forming minerals. CIM Special 11, 554560.

Foster, J.R., 1973. The efficiency of various digestion procedures on the extraction of metals from rocks and rockforming minerals. CIM Bulletin 66, 85-92.

Glumoff, S. \& Nikkarinen, M., 1991. Moreenin raskasmineraalifraktion geokemiallinen kartoitus Pielaveden Pyhäsalmen alueella. Summary: Regional geochemical mapping based on the heavy fraction of till in central Finland. Geological Survey of Finland, Report of Investigation $96,35 \mathrm{p}$.

Hirvas, $H ., 1980$. Moreenistratigrafiasta ja sen merkityksestä malminetsinnässä. Geologi No. 3 (in Finnish).

Hirvas, H. \& Nenonen, K., 1987. The till stratigraphy of Finland. INQUA Till Symposium, Finland 1985. Geological Survey of Finland, Special Paper 3.

Iisalo, E., 1992. Observations of the stratigraphy of Weichselian tills and subtill in Central Finland. Geological Survey Finland, Report of Investigation (in press).

Jackson, M.L., 1963. Aluminum Bonding in soils: a unifying principle in soil science. Soil Science Society of America Proceedings 27, $1-10$.

Kahma, A., 1973. The main metallogenic features of Finland. Geological Survey of Finland Bulletin 265, 28 p.

Kapoor, B.S., 1972. Weathering of micaceous clays in some Norwegian podzols. Clay Minerals 9, 383-394.

Kauranne, L.K., 1959. Pedogeochemical prospecting in glaciated terrain. Bull. Comm. Geol. Finland 184, 1-10.

Kauranne, K., Salminen, R. \& Äyräs, M., 1977. Problems of geochemical contrast in Finnish soils. In: Prospecting in areas of glaciated terrain 1977, IMM London, 34-44.

Kodama, H. \& Brydon, J.E. 1968. A study of clay minerals in podzol soils in New Brunswick, eastern Canada. Clay Minerals 7, 295-309.

Kodama, H., 1979. Clay minerals in Canadian soils: their origin, distribution and alteration. Canadian Journal of Soil Science 59, 37-58.

Koljonen, T., Gustavsson, N., Noras, P. \& Tanskanen, H., 1989. The Geochemical Atlas of Finland; preliminary aspects. Journal of Geochemical Exploration 32, 231241.

Kuosmanen, V., 1988 (Ed). Exploration target selection by integration of geodata using statistical and image processing techniques: an example from Central Finland. Part II, Atlas. Geological Survey of Finland, Report of Investigation $84,47 \mathrm{p}$.

Linden, A., 1975. Till petrographical studies in an Archaean bedrock area in southern central Sweden. Striae 1, 57 p. 
Lintinen, $P ., 1989$. Moreenin hienoaineksen savipitoisuuden vaikutuksesta geokemian analyyseihin. Unpublished M. Sc. Thesis, University of Helsinki (in Finnish).

MacEvan, D.M.C. \& Wilson, M.J., 1980. Interlayer and intercalation complexes of clay minerals. In: G. W. Brindley and G. Brown (Eds), Crystal structures of clay minerals and their X-ray identification. Mineralogical Society Monograph No. 5, London, 197-248.

McKeague, J.A. \& Day, J.H., 1966. Dithionite and oxalate extractable $\mathrm{Fe}$ and $\mathrm{Al}$ as aids in differentiating various classes of soils. Canadian Journal of Soil Science 46, $13-22$.

McKeague, J.A. \& Brydon, J.E., 1970. Mineralogical properties of ten reddish brown soils from the Atlantic provinces in relation to parent materials and pedogenesis. Canadian Journal of Soil Science 50, 47-55.

Melkerud, $P$-A., 1984. Distribution of clay minerals in soil profiles - A tool in Chronostratigraphical and lithostratigraphical investigations of till. Striae 20, 31-37.

Mehra, O.P. \& Jackson, M.L., 1960. Iron oxide removal from soils and clays by a dithionite-citrate system buffered with sodium bicarbonate. Clays and Clay Minerals 7, 317327.

Mäkinen, J., 1991. Similarity analysis using rank in till geochemistry. Bulletin of the Geological Society of Finland 63, Part I, 49-57.

Mäkinen, J., 1992. Glacial fractionation and relationships of unit weight to geochemical and mineralogical composition in the fine fraction of till. Bulletin of the Geological Society of Finland 64, 59-74.

Nevalainen, $R$., 1983. Moreenin hienoaineksen mineraalikoostumus ja kulkeutuminen Kuhmon liuskejakson alueella Kellojärvellä. Arkeeisten alueiden malmiprojekti, Raportti 8. University of Oulu (in Finnish).

Nieminen, $P$., 1985. Moreenin hienoaineksen laatu ja sen vaikutus routimisherkkyyteen. Tampere University of Technology. Publications 34, $81 \mathrm{p}$ (in Finnish).

Nikander, J., 1988. Mineralization. In: G. Gaàl (Ed). Exploration target selection by integration of geodata using statistical and image processing techniques: an example from Central Finland. Part I, Text, Geological Survey of Finland, Report of Investigation 80, 65-70.

Nikkarinen, M., Kallio, E., Lestinen, P. \& Äyräs, M., 1984. Mode of occurrence of $\mathrm{Cu}$ and $\mathrm{Zn}$ in till over three mineralized areas in Finland. Journal of Geochemical Exploration 21, 239-247.

Nuotio, T., Hyyppä, J. \& Nylander, E., 1990. Buffering capacity of Finnish soils and its dependence on geological factors in relation to the acidification sensitivity of lakes. In: P. Kauppi, P. Anttila \& K. Kenttämies (Eds). Acidification in Finland. Springer Verlag, Berlin, 271-286.

Nurmi, A., 1977. Exploration and applications of pedogeochemistry. PhD Thesis, University of Helsinki. Pawloski, G.A., 1985. Quantitative determination of mineral content of geological samples by X-ray diffraction. American Mineralogist 70, 663-667.

Perttunen, M., 1977. The lithologic relation between till and bedrock in the region of Hämeenlinna, southern Finland. Bulletin of the Geological Survey of Finland 291, 68 p.

Peuraniemi, V., 1982. Geochemistry of till and mode of occurrence of metals in some moraine types in Finland. Geological Survey of Finland Bulletin 322, 75 p.

Peuraniemi, V., 1990. The behaviour of the trace elements in the weathering crust in western Finnish Lapland. Chemical Geology 84, Special Issue, 118.

Punkari, M., 1980. The ice lobes of the Scandinavian ice sheet during the deglaciation in Finland. Boreas 9, 307-310.

Rainio, H. \& Lahermo, P., 1976. Observations on dark grey basal till in Finland. Bulletin of the Geological Society Finland, 48, 137-152.

Rencz, A.N.\& Shilts, W.W., 1980. Nickel in soils and vegetation of glaciated terrains. In: J.O. Nriagu, Nickel in the Environment. John Wiley \& Sons, Inc., 151-188.

Reynolds, R.C., 1980. Interstratified clay minerals. In: G. W. Brindley \& G. Brown (Eds). Crystal structures of clay minerals and their X-ray identification. Mineralogical Society Monograph No. 5, London, 247-303.

Rich, C.I., 1968. Hydroxy interlayers in expansible layer silicates. Clays and Clay Minerals 16, 15-30.

Räisänen, M.L., 1989. Mineraalimaan happamoituminen eräillä koealoilla teollisuuden lähiympäristössä ja taustaalueilla Suomessa. Summary: The acidification of podzolized mineral soils in background areas and near industrial areas in Finland. Geological Survey of Finland, Report of Investigation 91, $74 \mathrm{p}$ (in Finnish).

Räisänen, M.L. \& Jylänki, J., 1990. Mineraalimaan happamoituminen Marsjön-järven valuma-alueella Inkoossa. Imatran Voima Oy, T \& K-tiedotteita, IVO-B-04/90, 33 p (in Finnish, English Abstract).

Räisänen, M.L., Hämäläinen, L. \& Westerberg, M.-L., 1992. Selective extraction and analysis of metals in organic stream sediments. Analyst 117, Special CSI, (in press).

Saarnisto, M. \& Taipale, K., 1984. Influence of the Kuhmo Greenstone Belt (eastern Finland) upon the lithology and geochemistry of till. Striae 20, 39-44.

Salminen, $R . \&$ Hartikainen, A., 1985. Glacial transport of till and its influence on interpretation of geochemical results in North Karelia, Finland. Geological Survey of Finland Bulletin 335, 48 p.

Salonen, V-P., Tenhola, M. \& Murtoniemi, S., 1988. Quaternary geology. In: G. Gaàl (Ed). Exploration target selection by integration of geodata using statistical and image processing techniques: an example from Central Finland. Part I (Text), Geological Survey of Finland, Report of Investigation $80,60-64$.

Sawhney, B.L., 1977. Interstratification in layer silicates. In: J.B. Dixon and S.B. Weed (Eds). Minerals in Soil Environments, Soil Science Society of America, Madison, 
Wisconsin, 405-434.

Shilts, W.W., 1973. Glacial dispersal of rocks, minerals, and trace elements in Wisconsinan till, Southeastern Quebec, Canada. Geological Society of America Memoir 136, $189-219$.

Shilts, W.W., 1980. Geochemical profile of till from Longlac, Ontario to Somerset Island. CIM Bulletin 73, 85-94.

Sippola, J., 1974. Mineral composition and its relation to texture and to some chemical properties in Finnish subsoils. Annales Agriculturae Fenniae 13, 169-234.

Soveri, U. \& Hyyppä, J.M.I., 1966. On the mineralogy of fine fraction of some Finnish glacial tills. The State Inst. for Technical Research, Finland, Publication 113, 31 p.

Srodon, J. \& Eberl, D.D., 1984. Illite. In: S.W: Bayley (ed.) Micas. Mineralogical Society of America Short Course Notes, 495-544.

Toverud, Ö., 1974. Copper, lead and zinc anomalies in glacial overburden, northern Sweden. PhD Thesis, University of Stockholm, Sweden, 127 p.

Thorez, J., 1975. Phyllosilicates and clay minerals. A laboratory handbook for X-ray diffraction analysis. G. Lelotte, Dison, Belgique, $579 \mathrm{p}$.

Weaver, C.E., 1958. The effects and geologic significance of potassium »fixation» by exchangeable clay minerals derived from muscovite, biotite, chlorite and volcanic material. American Mineralogist 43, 839-861.

Weaver, C.E., 1989. Clays, muds, and shales. Developments in Sedimentology 44. Elsevier, Amsterdam, 1-186.

Whittig, l.D. \& Allerdice, W.R., 1986. X-ray diffraction techniques. In: A. Klute (ed). Methods of soil analysis, Part 1. American Society of Agronomy 9, Madison, Wisconsin U.S.A., 331-362.

Wilson, M.J., 1970. A study of weathering in a soil derived from a biotite-hornblende rock. I Weathering of biotite. Clay Minerals 8, 291-303.

Wilson, M.J., 1987. A handbook of determinative methods in clay mineralogy. Blackie \& Son Ltd, New York, 308 p.

Äyräs, M., 1977. Tilastollisia havaintoja alkuainejakautumista moreenin hienoaineksesa Sodankylässää. Summary: Statistical observations on the element distribution in the fine material of till, Sodankylä, northern Finland. Geological Survey of Finland, Report of Investigation No. 14, $36 \mathrm{p}$ (in Finnish).

Received January 2, 1992

Revision accepted May 15, 1992 